Международная Научно-Исследовательская Федерация «Общественная наука»

\title{
Научный диалог: Вопросы медицины
}

Сборник научных трудов

по материалам

X международной научной конференции

15 ноября 2017 г.

\section{SCIENCEPUBLIC}

Санкт-Петербург 2017 
УДК 001.1

ББК 60

Научный диалог: Вопросы медицины. Сборник научных трудов, по материалам международной научно-практической конференции 15.11.2017 г. Изд. ЦНК МНИФ «Общественная наука», 2017. - 36с.

\section{SPLN 001-000001-0205-MQ \\ DOI 10.18411/spc-15-11-2017 \\ IDSP 000001:spc-15-11-2017}

В сборнике научных трудов собраны материалы из различных областей научных знаний. $\mathrm{B}$ данном издании приведены все материалы, которые были присланы на $\mathrm{X}$ международную научно-практическую конференцию Научный диалог: Вопросы медицины

Сборник предназначен для научных работников, преподавателей, аспирантов и студентов.

Все материалы, размещенные в сборнике, опубликованы в авторском варианте. Редакция не вносила коррективы в научные статьи. Ответственность за информацию, размещенную в материалах на всеобщее обозрение, несут их авторы.

Информация об опубликованных статьях будет передана в систему Российского индекса научного цитирования (РИНЦ) и наукометрическую базу SPINDEX

Электронная версия сборника доступна на сайте ЦНК МНИФ «Общественная наука». Сайт центра: conf.sciencepublic.ru

УДК 001.1

ББК 60 


\section{Содержание}

Богатырева Ю.А., Чиркова Н.В., Агафонов А.Н., Орешкина Д.А., Деревнина Н.Г. Сравнительная индексная оценка применения реминерализующих препаратов для профилактики осложнений при лечении дисколоритов зубов

Богатырева Ю.А., Крючков М.А., Гордеева Т.А., Грачев М.А., Елисов Д.К. Мотивация пациентов к проведению профилактики, направленной на предупреждение возникновения осложнений при лечении дисколоритов зубов

Кавалерский Г.М., Петров Н.В., Бровкин С.В., Катунян П.И., Дрогин А.Р., Карев А.С., Германов В.Г., Хурцилава Н.Д., Целищева Е.Ю. Применение перфторана при лечении открытых переломов длинных трубчатых костей

Климкина Т.Н.,Дубов В.С., Красная А.А., Курындина И.А. Гиалуроновая кислота как триггер развития аутоиммунного воспалительного синдрома, индуцированного адъювантами

Кузнецов С.И., Овсянникова В.В. Метаболическая терапия у больных артериальной гипертензией

Полушкина Н.А., Чиркова Н.В., Зубкова Т.В., Адамян Г.Г., Бобешко М.Н. Проведение бактериологического исследования полости рта пациентов с сахарным диабетом при протезировании съемными конструкциями

Трошкова В.Н., Давыдова Э.К., Байда К.Ю., Трошков А.М. Разработка универсального мобильного локализатора с очистителем воздуха для первичной обработки огнестрельных ранений конечностей

Фомина К.А., Чиркова Н.В., Вечеркина Ж.В., Калиниченко В.С., Кончакова В.В. Определение токсикологических показателей безопасности дезинфектанта для съемных зубных протезов из термопластических материалов.

Фролова А.В., Орлова М.М., Родионова Т.И. Значение цитокинового ответа в развитии поражения сердечно-сосудистой системы при диффузном токсическом зобе 27

Чиркова Н.В., Плутахина А.А., Лещева Е.А., Машкова Н.Г., Кузнецов Д.Э. Изучение комплаентности и ее взаимосвязи со стоматологической заболеваемостью у студентов

Чиркова Н.В., Вавина А.П., Корецкая И.В., Мамонтова А.М.,Колесников И.Р. Изучение основных проблем современной эндодонтии - микробной флоры биопленки 


\section{Богатырева Ю.А., Чиркова Н.В., Агафонов А.Н., Орешкина Д.А., Деревнина Н.Г. Сравнительная индексная оценка применения реминерализующих препаратов для профилактики осложнений при лечении дисколоритов зубов}

Воронежский государственный медицинский университет им.Н.Н. Бурденко» Министерства Здравоохранения РФ (Россия, Воронеж)

doi:10.18411/spc-15-11-2017-01

idsp: 000001:spc-15-11-2017-01

Консервативным методом лечения дисколоритов - изменения цвета зубов является процедура отбеливания. Известно, что временное нестойкое окрашивание могут вызвать пищевые красители (ягоды черники, красное вино, кофе, крепкий чай и др.), лекарственные средства, развитие грибка Lichen dentalisв зубном налете, производственные вредности. Для устранения временного окрашивания обычно достаточно тщательного гигиенического ухода за полостью рта и проведение профессиональной гигиены. Стойкое окрашивание зубов может быть обусловлено нарушением формирования твердых тканей зубов (флюорозом, несовершенным амелои дентиногенезом, тетрациклиновыми зубами и др.) и изменением цвета после прорезывания (возрастные изменения, травма зуба, депульпирование зуба и др.). В таком случае проводится процедура наружного, внутреннего или комбинированного отбеливания, которое проводится или в домашних условиях или в кабинете стоматолога. Наиболее частым осложнением, возникающим после воздействия отбеливающих препаратов является гиперчувствительность зубов.

В стоматологической поликлинике ВГМУ им. Н.Н. Бурденко было обследовано 60 пациентов в возрасте 25 - 42 лет, обратившихся по поводу лечения дисколоритов витальных зубов. В зависимости от применяемого метода реминерализующей терапии они были разделены на четыре группы:

- первая группа - 15 человек с целью уменьшения повышенной чувствительности зубов использовала лечебно-профилактическую зубную пасту «Sensitive»(«Сплат-косметик» г. Москва);

- вторая группа -15 человек - «Фторлак - Белак-F»(«ВладМива», Россия);

- третья группа - 15 человек - «Гипостез -фтор» (ООО «Радуга Р», Россия);

- четвертая группа - 20 человек - «Сенсидент», с последующей обработкой бесцветным фторсодержащим лаком «Флюрофил» (ОOО «Целит», Россия) (табл.1).

Таблица 1 .

Распределение пациентов с дисколоритом витальных зубов в зависимости от применения методов реминерализующей терапии

\begin{tabular}{|c|c|c|}
\hline № группы & Количество & Рекомендованный метод реминерализующей терапии \\
\hline 1 группа & 15 & $\begin{array}{c}\text { «Sensitive» - зубная паста для снятия чувствительности зубов и } \\
\text { восстановления эмали }\end{array}$ \\
\hline 2 группа & 15 & «Фторлак - Белак-F» (ООО«ВладМива», Россия) \\
\hline 3 группа & 15 & «Гипостез - фтор» (ООО «Радуга Р», России $)$ \\
\hline 4 группа & 15 & $\begin{array}{c}\text { «Сенсидент», с последующей обработкой бесцветным } \\
\text { фторсодержащим лаком «Флюрофил» (ООО «Целит», Россия). }\end{array}$ \\
\hline
\end{tabular}

Фирмой «Целит» (г. Воронеж)предложен препарат «Сенсидент» - гель, в состав которого входят соли калия. Ионы калия, накапливаясь в дентинных канальцах, блокируют передачу нервных импульсов.

Фторлак «Флюрофил бесцветный» содержит фторид натрия и фторид кальция в ионной форме. Малый размер частиц обеспечивает длительное и глубокое 
проникновение фтора и кальция в твердые ткани зуба, в частности, в дентинные канальцы. Образующаяся при нанесении данного фторлака на поверхности зуба пленка бесцветна, что имеет эстетическое значение для многих пациентов. Проводили оценку реминирализующей терапии у пациентов после процедуры отбеливания в ближайшие и отдаленные сроки для анализа и сопоставления данных оценки индекса распространенности (ИРГЗ) и индекса интенсивности (ИИГЗ) гиперестезии.

Оценку гиперестезии дентина проводили по величине показателя индексов распространения гиперестезии зубов (ИРГЗ) и интенсивности гиперестезии зубов (ИИГЗ) (Шторина Г.Б., 1986). Расчет проводили по формуле:

$$
\text { ИРГЗ }=\underline{\text { количество зубов с повышенной чувствительностью }} \times 100 \%
$$

$$
\text { количество зубов у данного пациента }
$$

В зависимости от распространенности гиперестезии твердых тканей зубов, то есть от того, сколько зубов имеет повышенную чувствительность к различным раздражителям, величина индекса варьирует в пределах от 3,1 до 100\%. При значениях индекса от 3,1 до 25\% диагностируют ограниченную форму гиперестезии твердых тканей зуба, при генерализованной форме значения индекса находятся в пределах 26$100 \%$.

Для более объективной оценки чувствительности твердых тканей зубов предложен индекс интенсивности гиперестезии зубов, который рассчитывается по формуле:

$$
\text { ИИГЗ }=\frac{\text { сумма значений индекса у каждого зуба }}{\text { количество зубов с повыпенной чувствительностью }}
$$

И рассчитывается в баллах:

0 - отсутствие реакции на температурные, химические и тактильные раздражители;

1 - наличие чувствительности к температурным раздражителям;

2 - наличие чувствительности к температурным и химическим раздражителям;

3 - наличие чувствительности к температурным, химическим и тактильным раздражителям.

Значения индекса интенсивности гиперестезии твердых тканей зубов находится в пределах от 1,0 до 3,0 баллов. При значениях индекса от 1,0 до 1,5 - гиперестезия 1 степени; от 1, 6 до 2,2 балла - гиперестезия 2 степени; от 2,3 до 3,0 баллов гиперестезия 3 степени.

Оценку проводили у пациентов четырех групп до и после химического отбеливания, непосредственно после реминерализирующей терапии и спустя 6, 12 месяцев после лечения.

Сразу после процедуры отбеливания в первой группе определялась

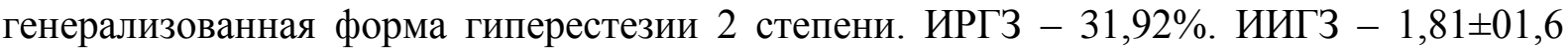
балла. Непосредственно после реминерализующей терапии с использованием лечебнопрофилактической пасты отмечалось наличие гиперестезии. Значение ИРГЗ -14,9\%, ИИГЗ - 1,13 $\pm 0,29$ баллов. Через 6 месяцев показатель ИРГЗ составил 17,9\%, ИИГЗ -

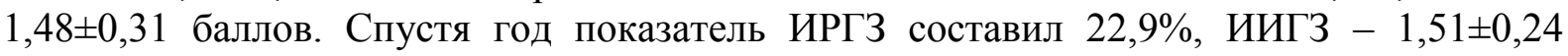
баллов.Отмечалось наличие ограниченной гиперестезии 1 степени, признаки которой полностью ликвидировать не удалось.

Проводили оценку результатов эффективности реминерализующей терапии с использованием «Фторлак - Белак-F» у пациентов 2 группы. После отбеливания отмечалось появление гиперестезии 2 степени, так же как у пациентов 1 группы. ИРГЗ

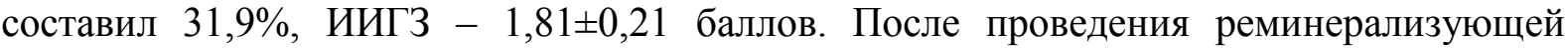
терапии значения ИИГЗ И ИРГЗ снизились и составили $6,5 \%$ и $1,15 \pm 0,12$ баллов, что указывало на наличие гиперестезии 1 степени. Спустя 6 месяцев значения ИРГЗ 


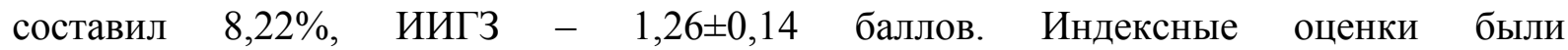
удовлетворительными.

Проводили оценку результатов эффективности реминерализующей терапии с использованием «Гипостез»у пациентов 3 группы. После отбеливания отмечалось

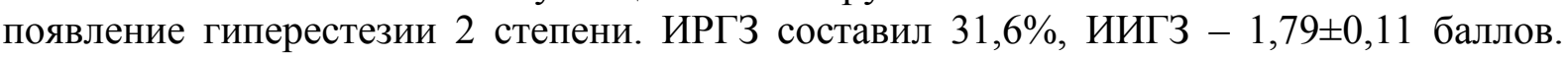
После проведения реминерализующей терапии значения ИИГЗ И ИРГЗ снизились и составили $6,1 \%$ и $1,05 \pm 0,21$ баллов, что указывало на наличие гиперестезии 1 степени.

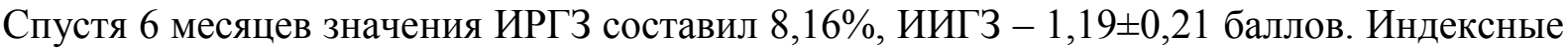
оценки были удовлетворительными.

Пациентам 4 группы после химического отбеливания проводили реминерализующую терапию с использованием «Сенсидент», с последующей обработкой бесцветным фторсодержащим лаком «Флюрофил». После процедуры отбеливания появились признаки генерализованной гиперестезии 2 степени. ИРГЗ $31,01 \%$, ИИГЗ - 1,79 $\pm 0,13$ баллов. Непосредственно после реминерализующей терапии признаков гиперестезии не наблюдалось и оставались на нулевой отметке после 6 и 12 месяцев наблюдения.

Таким образом, после окончания срока наблюдения наиболее положительные результаты реминерализующей терапии отмечали в 4 группе, пациентам которой был использован «Сенсидент», с последующей обработкой бесцветным фторсодержащим лаком «Флюрофил», что доказывало его эффективность.

1. Коммунальная стоматология: учебно-методическое пособие / А.Н. Морозов и [др.] // - Воронеж, 2016. $-125 \mathrm{c}$.

2. Профилактическая коммунальная стоматология. / П.А. Леус. - М.: «Медицинская книга». - Москва, 2008. $-444 \mathrm{c}$.

3. Профилактическая соматология: Учебник / Э.М. Кузьмина, О.О. Янушевич. - М.: Практическая медицина, 2017. - 544 с.

4. Эффективность применения фторлака фирмы «Целит» для лечения гиперестезии эмали при различной $\mathrm{pH}$ ротовой жидкости / Т.А. Попова и [др.] // Тенденции науки и образования в современном мире, 2016. -№ 19-2. -С. 35-37.

5. Чиркова Н.В. Аспекты влияния профессионального отбеливания на твердые и мягкие ткани полости рта / Н.В. Чиркова и [др.] // Medicus international medical journal, 2017. - № 4 (16). - С. 60-70.

Богатырева Ю.А., Крючков М.А., Гордеева Т.А., Грачев М.А., Елисов Д.К.

Мотивация пациентов к проведению профилактики, направленной на предупреждение возникновения осложнений при лечении дисколоритов зубов

Воронежский государственный медицинский университет им.Н.Н. Бурденко» Министерства Здравоохранения РФ (Россия, Воронеж)

doi:10.18411/spc-15-11-2017-02

idsp: 000001:spc-15-11-2017-02

В последние годы эстетическая стоматология в нашей стране становится всё более востребованной, поскольку красивые зубы - это элемент современной культуры, символ молодости, здоровья, красоты и успеха. Дисколорит зубов - это распространенная и многофакторная по природе патология, составляющая актуальную проблему стоматологии, с одной стороны, связанную с эстетическим дефектом, a, с другой стороны, с несовершенством существующих методов лечения. Временное нестойкое окрашивание могут вызвать разнообразные пищевые красители, такие как ягоды смородины, вишни и черники, красное вино, гранатовый сок, кофе, крепкий чай и др., некоторые лекарственные препараты, развитие грибка Lichen dentalisв зубном налете, а также работа на предприятиях, связанных с изготовлением медных, латунных и бронзовых изделий. Для устранения временного окрашивания обычно достаточно 
тщательного гигиенического ухода за полостью рта и проведение профессиональной гигиены. Однако, стойкое окрашивание зубов может быть обусловлено нарушением формирования твердых тканей зубов, например флюорозом, несовершенным амело- и дентиногенезом, тетрациклиновыми зубами, врожденной эритропорфией, гемолитической болезнью новорожденных. Изменение цвета зубов после прорезывания связано с курением, возрастными изменениями, начальным кариесом, травмой зуба, депульпированием зуба, пломбами из амальгамы, пломбированием каналов резорцин-формалиновой пастой, использованием штифтов из неблагородных металлов. Однако имеются и противопоказания к отбеливанию зубов: эрозии, рецессия десны, крупная камера пульпы зуба, значительная убыль эмали в результате повышенного стирания, глубокие трещины на поверхности эмали, воспалительные заболевания пародонта в период обострения, наличие кариозных полостей и наличие ортодонтических конструкций. Кроме того процедуру отбеливания не рекомендуется проводить в период беременности и кормления грудью, несовершенолетним пациентам, лицам с аллергической реакцией на перекись водорода, перекись карбамида и карбопол.

При дисколоритах проводится процедура наружного, внутреннего или комбинированного отбеливания в домашних условиях или в кабинете стоматолога. Наиболее частым осложнением, возникающим после воздействия отбеливающих препаратов является очаговая деминерализация эмали, гиперчувствительность зубов, воспаление тканей пародонта.

Перед процедурой отбеливания для профилактики осложнений, необходимо обучить пациента методике чистки зубов и использованию зубных нитей, провести профессиональную гигиену полости рта и полировку зубов мелкоабразивными пастами, определить цвет зубов с использованием шкалы Vita и защитить десну и слизистую оболочку рта кофердамом.

Разработан алгоритм проведения профилактических мероприятий у пациентов после лечения дисколоритов:

1. Проведение осмотра полости рта пациента, оценка состояния твердых тканей зубов и тканей пародонта.

2. Проведение контролируемой чистки зубов с определением индекса гигиены.

3. Подбор средств индивидуальной гигиены полости рта: зубной пасты, ополаскивателя, обладающими реминерализующими свойствами, средств для снятия повышенной чувствительности зубов; зубных нитей.

4. Назначение и проведение реминерализующей терапии.

5. Проведение профессиональной гигиены полости рта 1 раз в 6 месяцев.

6. Мотивация пациента к ежедневному, тщательному уходу за полостью рта, регулярному посещению стоматолога, отказ от курения.

В течение двух недель после проведения процедуры отбеливания необходимо объяснить пациенту, что нельзя принимать пищу и напитки, содержащие красители и курить.

Известно, что наиболее популярным средством для осветления зубов в домашних условиях являются отбеливающие зубные пасты. Существуют несколько групп отбеливающих зубных паст:

- высокоабразивные зубные пасты или пасты для курильщиков;

- отбеливающие зубные пасты, содержащие ферменты;

- отбеливающие зубные пасты, содержащие красители.

Высокоабразивные зубные пасты должны применяться не чаще 2 раз в неделю. При их использовании достигается эффективное удаление налета за счет большого количества абразивных единиц. Следует помнить, что избыточное воздействие 
приводит к истиранию эмали и появлению чувствительности зубов. В настоящее время в такие зубные пасты, как правило вводят полирующие системы, поэтому они могут использоваться для ежедневного применения с целью поддержания естественной белизны зубов.

Использование отбеливающих зубные пасты, содержащие ферменты(папаин, бромелаин, полидон) позволяет достигать отбеливающий эффект за счет удаления зубного налета путем ферментативного расщепления белков его органической матрицы. Такие зубные пасты имеют абразивы средней степени, могут быть рекомендованы для ежедневного использования с длительностью курса 3 месяца.

Эффект применения отбеливающих зубных паст, содержащие окислители (перекись водорода, перекись карбамида) основывается на использовании атомарного кислорода, окисляющего пигменты и осветляющего твердые ткани зуба.

Однако, бесконтрольное применение отбеливающих зубных паст может привести к деминерализации эмали, развитию кариеса, гиперчувствительности зубов и воспалению десны.

$$
\text { *** }
$$

1. Коммунальная стоматология: учебно-методическое пособие / А.Н. Морозов и [др.] - Воронеж, 2016. $-125 \mathrm{c}$.

2. Современные возможности профилактики стоматологических заболеваний / А.А. Кунин [и др.] // Системный анализ и управление в биомедицинских системах. - 2008. - Т. 7.- № 1. - С. 188-191.

3. Пропедевтика хирургической стоматологии: учебное пособие / А.Н. Морозов и [др.]. // Международный журнал прикладных и фундаментальных исследований. 2014. № 3. С. 158-159.

4. Профилактическая коммунальная стоматология. / П.А. Леус. - М.: «Медицинская книга». - Москва, 2008. - $444 \mathrm{c}$.

5. Профилактическая соматология: Учебник / Э.М. Кузьмина, О.О. Янушевич. - М.: Практическая медицина, 2017. - 544 с.

6. Чиркова Н.В. Аспекты влияния профессионального отбеливания на твердые и мягкие ткани полости рта / Н.В. Чиркова и [др.] // Medicus international medical journal, 2017. № 4 (16). - С. 60-70.

Кавалерский Г.М., Петров Н.В., Бровкин С.В., Катунян П.И., Дрогин А.Р., Карев А.С., Германов В.Г., Хурцилава Н.Д., Целищева Е.Ю. Применение перфторана при лечении открытых переломов длинных трубчатых костей

Первый Московский Государственный медицинский университет им. И.М.Сеченова (Россия, Москва) doi:10.18411/spc-15-11-2017-03

idsp: 000001:spc-15-11-2017-03

Лечение больных с тяжелыми открытыми переломами является до конца не решенной проблемой. Количество неудовлетворительных результатов наблюдается у 30-60\%\% пострадавших (6). Тяжесть патологии объясняется сочетанием костной травмы с дефектом мягких тканей, что обуславливает развития воспалительных осложнений и большого количества несращений $(1,6,7)$. Сами методы лечения до сих пор остаются дискутабельными. Если в вопросах фиксации отломков травматологи едины, отдавая предпочтение внеочаговому остеосинтезу, то в вопросах ликвидации дефекта мягких тканей имеются разногласия.

При высоэнергетической травме наблюдаются выраженные изменения в зоне ушиба в виде гипоксии тканей, нарушения микроциркуляции, кислотно-щелочного равновесия $(1,2,6,7,8)$. Развивающийся в последствие посттравматический отек еще больше усугубляет жизнеспособность тканей, и при швах с натяжением или попытке устранить дефект с помощью пластики местными тканями практически всегда развивается некроз $(6,7)$. Методом выбора при ликвидации дефекта мягких тканей в остром периоде является свободная кожная аутопластика (7). Однако, принимая во 
внимание ухудшение микроциркуляции, условия для приживления свободного трансплантата, питание которого осуществляется путем диффузии со дна раны, будут недостаточно адекватными.

В связи с этим наше внимание привлек препарат перфторан, который, поступая в кровеносную и лимфатическую системы, обладает свойством транспортировать кислород, улучшая оксигенацию, микроциркуляцию $(3,4,5,8)$. Степень гипоксии тканей в зоне ушиба и эффективность использования перфторана при открытых переломах IO 2, IO 3, IO 4 типов по классификации AO ASIF (10) определялись путем изучения напряжения кислорода (pO2) методом полярографии у 25 больных с открытым переломом плеча (3 больных), предплечья (2 больных), голени (16 пострадавших) и бедра (4 пострадавших) в остром периоде травматической болезни до и после местного применения препарата.

Исследование осуществлялось на полярографе «Оксиметр-М» по следующей методике. В операционной после основных этапов ПХО в пораженные ткани на расстоянии 0,5 - 1,0 см от края раны вводился поочередно внутрикожно и подкожно встроенный в тонкий тефлоновый проводник активный стериль-ный платиновый электрод. Пассивный хлорсеребряный электрод накладывался на одноименное предплечье. Производили исходное измерение напряжения кислорода. Затем подкожно, паравульнарно, отступя от краев раны на 5 - 6 см (во избежание вытекания препарата), по всему периметру окружности раны в дозе 0,1-0,5 мл/кг массы тела пострадавшего (в среднем 35-40 мл.), и повторно измеряли рО2. Полученные цифровые данные переносились на предварительно построенную калибровочную кривую для перевода условных единиц электрического сопротивления тканей (Па/нА) в величину напряжения кислорода (pO2) в мм. рт. ст. Результаты измерения представлены графически на рисунках 1,2, 3 .

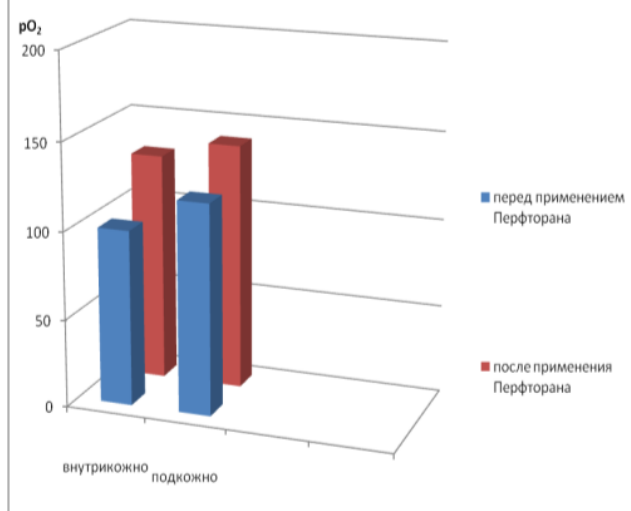

Рис. 1. Исходное напряжение кислорода в зоне ушиба и и после введения перфторана при переломе ОI 2 типа.

Рис. 2. Исходное напряжение кислорода в зоне ушиба ии после введения перфторана у больных с переломами IО 3 типа. 


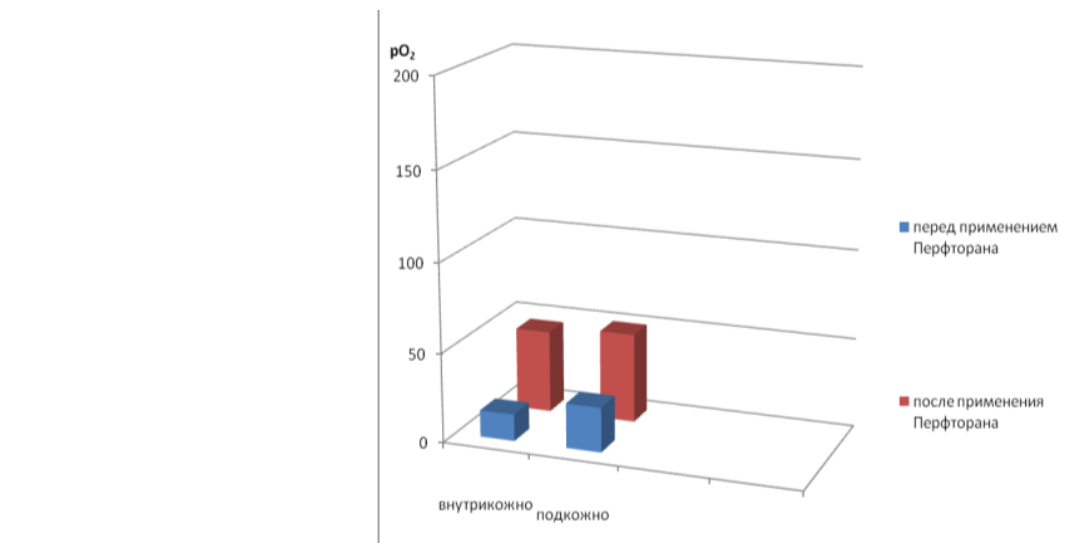

Рис. 3. Исходное напряжение кислорода в зоне ушиба и после введения перфторана у больньх с переломами IO 4 типа.

Как видно из приведенных графиков, первоначальное полярографическое исследование (до введения перфторана) позволило выявить выраженное местное нарушение кислородного режима в зоне ушиба при тяжелой (IO 3 и IO 4 типов) травме мягких тканей как внутри-, так и подкожно. И, напротив, при нетяжелой травме (переломы IO 2 типа) нарушение кислородного режима выражено в значительно меньшей степени.

При сравнении графиков установлено, что введение перфторана у больных с переломами IO 3 степени дает возможность, благодаря интенсивной диф-фузии кислорода к капиллярам пораженных тканей в зоне ушиба, значительно улучшить тканевое дыхание. Тем самым предотвращается вторичная циркуляторная гипоксия, которая нередко приводит к углублению микронекроза (5).

Введение перфторана у больных с переломом IO 4 тип улучшает кислородное обеспечение в значительно меньшей степени.

На основании этого были разработаны показания к применению перфторана и методики ликвидации дефектов мягких тканей в зависимости от тяжести открытых переломов. Так, при переломах IO 2 степени перфторан можно не вводить, т.к. выраженных местных патологических изменений нет, и рана ликвидируется с помощью наложения швов с насечками или пластики местными тканями. При переломах IO 3 и IO 4 степени показано введение перфторана, но последующая оперативная тактика будет различна. При IO 3 степени кислородное обеспечение настолько улучшается, что может быть предпринята попытка одномоментной ликвидации дефекта. При локализации перелома на сегментах с большим мышечным массивом (плечо, бедро и, как исключение, голень) мы сочли возможным устранить дефект, шириной до 6 см, с помощью местной пластики путем перемещения кожных лоскутов у 7-и пострадавших или наложения швов с насечками в шахматном порядке в их окружности у 2-х больных с переломами предплечья и у 4-х с переломом бедра.

При открытых переломах IO 4 степени тяжесть травмы мягких тканей столь велика, что применение перфторана лишь незначительно снижает их гипоксию, не создавая условий для ликвидация ран любым способом. Этим больным на заключительном этапе операции первичной хирургической обработки после внеочаговой фиксации отломков на рану накладывалась повязка с раствором антисептика с последующей, через 3-4 суток, повторной хирургической обработкой (second look), которая заканчивается свободной кожной пластикой. Отмечено, что после введения перфторана катаболические процессы в ранах протекают более интенсивно с четким отграничением некротических тканей в короткие сроки.

Таким образом, в остром периоде травматической болезни при переломах IO 2 типа отсутствуют выраженные признаки гипоксии, что дает основание ликвидировать 
дефект мягких тканей без предварительного введения перфторана. При переломах IO 3 типа после применения перфторана гипоксия значительно снижается, что позволяет ликвидировать дефект мягких тканей различными способами кожной пластики, а при переломах IO 4 типа снижение гипоксии после введения перфторана было незначительным, что делает невозможным любые вмешательства на мягких тканях с цель устранения их дефекта.

$$
* * *
$$

1. Афанасьев Л.М. Профилактика послеоперационных гнойных осложнений у больных с открытыми сочетанными повреждениями конечностей и их последствиями. Сб. тезисов 9 съезда травматологовортопедов России, Саратов, 2010, т. 3, с.1047-1048.

2. Борисова В.Ю. с соавт. Особенности первичной хирургической обработки высокоэнергетических открытых переломов голени. Сб тез. докладов 8 съезда травматологов-ортопедов России, Самара 2006 г, т. 1., с. 145-146.

3. Иваницкий Г.Р. Как перфторан обеспечивает газотранспорт. Сб. «Перфторорганические соединения в биологии и медицине», Пущино, 1999, с. 229-243.

4. Клигуленко Е.Н. с соавт. Местное применение перфторана в ком-плексном лечении длительно заживающих ран. Сб. «Перфторорганические соединения в биологии и медицине», Пущино, 1999, с.146-150.

5. Маевский Е.И. с соавт. Оценка газотранспортных свойств эмульсии перфтоорганических соединений по реакциям митохондрий. Сб. «Перфтораноорганические соединения в биологии и медицине», Пущино, 1999 г., с. 243-254.

6. Петров Н.В. с соавт. Профилактика осложнений при открытых переломах голени с дефектом мягких тканей. Сб тезисов докладов 8 съезда травматологов-ортопедов России, Самара, 2006 г., т.2, с.1139.

7. Петров Н.В. с соавт. К вопросу об особенностях лечения открытых переломов голени с дефектом мягких тканей. Тр. Всероссийск. Научн. Конф. «Новые технологии в ВПХ и хирургии повреждений», Санкт-Петерб., 2006 г., с. 72.

8. Софронов Г.А. с соавт. Применение перфторана в военной медицине. Сб. «Перфтораноорганические соединения в биологии и медицине», Пущи-но, 1999 г., с.21-25.

9. Федосеев М.М. Повторная хирургическая обработка огнестрельных ранах конечностей в условиях специализированного отделения. Сб. тезисов 1Х съезда травматологов-ортопедов, Саратов, 2010, т.1, с. 272-273.

10. Muller M.E. et all. The AO Classificftion of fractures Springer - Verlag Berlin-Heidelberg-New-Jork, 1987.

\section{Климкина Т.Н.,Дубов В.С., Красная А.А., Курындина И.А. Гиалуроновая кислота как триггер развития аутоиммунного воспалительного синдрома, индуцированного адъювантами}

«Тихоокеанский государственный медицинский университет» Минздрава России (Россия, Владивосток)

\section{Аннотация:}

В работе было проведено исследование пациентов, которые обратились с различными жалобами, характерными для системных заболеваний соединительной ткани, но полностью не соответствующие диагностическим критериям известных нозологий. Сбор анамнеза пациентов и результаты исследований подтвердили наличие подкожных инъекций гиалуроновой кислоты в предшествующие 2 года, а так же клинико-лабораторные изменения, характерные для проявлений системных заболеваний соединительной ткани. С учетом исключения других факторов, которые могли бы послужить причиной таких изменений, был сделан вывод о возможной роли гиалуроновой кислоты выступать в роли адъюванта, запускающего аутоиммунный воспалительный синдром.

\section{Abstract}

In the work, a study was carried out of patients who addressed various complaints characteristic of systemic connective tissue diseases, but did not completely correspond to the diagnostic criteria of known nosologies. The history of patients and the results of the studies 
confirmed the presence of subcutaneous injections of hyaluronic acid in the previous 2 years, as well as clinical and laboratory changes characteristic of manifestations of systemic diseases of connective tissue. Taking into account the exclusion of other factors that could cause such changes, a conclusion was made about the role of hyaluronic acid in acting as an adjuvant, which triggers an auto-inflammatory syndrome.

Подкожные инъекции гиалуроновой кислоты имеют широкое применение в косметологии. До недавних пор они считались абсолютно безопасной процедурой. Но на сегодняшний день считается достаточно достоверным участие гиалуроновой кислоты в развитии аутоиммунного воспалительного синдрома, индуцированного адъювантами (ASIA). ASIAбыл предложен израильскими иммунологом ИегудойШонфельдом в 2011 году, является предположительно аутоиммунным заболеванием, провоцируемым адъювантами, в роли которых могут выступать соли алюминия, силикон, сквален, различные компоненты вакцин, а так же предположительное многие другие компоненты, обладающие иммунореактивностью[1,2]. Адъюванты - это вещества, используемые для усиления иммунного ответа при одновременном его введении с иммуногеном. Адъюванты являются не только стимуляторами иммунитета, они обладают одной очень важной особенностью - модификацией иммунного ответа [3]. Во-первых, адъюванты, в нашем случае роль идет о гиалуроновой кислоте, приводят к асептическому воспалению, результатом которого является регенерация и модификация компонентов соединительной ткани. Во-вторых, адъюванты приводят к изменению антигенной структуры вводимого компонента, делая его антигенность и иммуногенность наиболее выраженной и привлекательной для клеток гуморального иммунитета. И в-третьих, адъюванты увеличивают время персиситирования вводимых компонентов в тканях. Тем самым они обладают колоссальным риском развития перекрестной аутоиммунной реакции на компоненты собственных продуктов соединительной ткани и особенно на гиалуроновую кислоту [4].

\section{Цель исследования:}

Изучение возможности гиалуроновой выступать в роли триггера развития аутоиммунного воспалительного синдрома, индуцированного адъювантами на основании изучения острофазовых показателей и маркеров заболеваний соединительной ткани.

\section{Материалы и методы исследования:}

В период с 10.10.2016-10.10.2017 была отобрана и сформирована группа из 11 человек, имеющих сходные особенности с клиническим течением синдрома Шонфельда. Распределение по полу составило - 7женщин и 4мужчин. Возрастная медиана - 43 года. Пациенты были отобраны в исследование по следующим критериям: подкожные инъекциигиалуроновой кислоты и/или других филлеров в предшествующие 2 года и менее, отсутствие клинически подтвержденных системных заболеваний соединительной ткани, значения клинических анализов в пределах лабораторных норм за период не менее 12 месяцев до настоящего обращения, возраст менее 50 лет, отсутствие на период исследования острых заболеваний различной этиологии.Была проведена оценка и распределены по наибольшей частоте встречаемости следующие симптомы : артралгия суставов любой анатомической области, миалгия, кожные проявления по типу васкулита, эритему области лица и декольте, немотивированный подъем температуры тела выше 36.9 градусов, лимфаденопатию, немотивированную усталость, повышенную ломкость ногтей и волос.Длявключение в исследование пациенты должны были иметь два и более проявления вышеописанных реакций. Всей группе было произведено количественное определение и расчет: лейкоцитов, показателей С-реактивного белка, уровня АЛТ, АСТ, ЛДГ, ЩФ, фибриногена, ревматоидного фактора, волчаночных клеток, СОЭ, креатинина сыворотки, мочевины, СКФ, уровня кальция, калия и натрия в сыворотке.

\section{Результаты исследования:}


По результатам исследования частота встречаемости жалоб имела следующие особенности. Чаще всего встречались наиболее неспецифические жалобы: артралгия наблюдалась в $72 \%$ случаев, распространённые и локализованная миалгии в $63 \%$ случаев, лихорадка свыше 36.9 градусов в 45\%, хроническая усталость и выраженная астения без объективной причины имела место у 45\% исследуемых, изменения кожи по типу эритемы, экземы, дерматоза неясного генеза встречались в 36\% случаев, а воспалительные моноартриты и распространенная лимфаденопатия имела место у $27 \%$ обследуемых.

Повышенный уровень СРБ имел место у 64\% исследуемых ( средний показатель - 34мл/дл, референсные величины: <0.5 мг/дл), ЛДГ у 27\% исследуемых (средний показатель - 347Ед/л, референсные величины: 1-248 ЕД/л), ЩФ у 25\% ( средний показатель - 171 Ед/л, референсные величины: 30-124 Ед/л), уровень фибриногена у 54 \% ( средний показатель - 4,6 г/л, референсные величины: 1,6 - 4 г/л), волчаночные клетки у 27\%, ревматоидный фактор у $18 \%$ ( средний показатель - 64MЕ/Л, референсные величины - <30МЕ/Л) СОЭ у 62,5\% ( средний показатель - 24 мм/ч, рефересные величины: 2-15 мм/ч), повышенный уровень лейкоцитов у 25\% ( средний показатель $-9.2^{*} 10^{\wedge} 9 / л$, референсные величины: 4-9*10^9/л). Изменений со стороны УЗИ органов брюшной полости, щитовидной железы, уровня креатинина, мочевины, СКФ, а так же ионного состава выявлено не было.

\section{Обсуждение:}

Результаты, полученные при исследовании, указывают на системный воспалительный процесс, застрагивающий соединительную ткань. Такие изменения характерны для системных заболеваний соединительной ткани. Однако отсутствие клинико-лабораторных данных, указывающих на поражение органов-мишеней при истинных заболеваниях соединительной ткани, позволяет предположить аутоиммунную воспалительную реакцию, которая должна быть расценена как непосредственно ASIAв связи с достоверной информацией о контакте с триггеромадъювантом (гиалуроновой кислотой). Так же с учетом отсутствия информации о возможном переходе ASIAв истинные аутоиммунные заболевания, получение таких результатов у пациентов всегда должны относить их в группу высокого риска и более тщательного длительного контроля.

Недавние исследования показывают, что антитела к ДНК способны вступать в реакцию с гиалуроновой кислотой, гепарин сульфатом и хондроитин сульфатом у пациентов с системной красной волчанкой. Кроме того, повышенный уровень антител кгиалуроновой кислоте коррелирует с агрессивностью течения заболевания. Подобные данные были обнаружены в сыворотки крови больных с аутоиммунными заболеваниями щитовидной железы. То есть, существует прямая связь и корреляция между выраженностью аутоиммунных заболевания соединительной ткани и содержаниемантител к глюкозаминогликанам, [5].Так же в 2017 году в крупном скрининге Y. Shoenfield, A. Watard и коллег было признано, что косметические филлеры являются триггерами развития системных реакций в $38 \%$ случаев [6]. В дополнение к вышеперечисленным результатам был проведен анализ пациентов после введения им гиалуроновой кислоты, гиалуроновой кислоты с акриловым гидрогелем. Из 25 пациентов у 15 имелись проявления иммуномодулированнных расстройств. Среднее время развития симптомов составляло 13.7 месяцев причем, возрастная коррекция имела прямую корреляцию. У $30 \%$ имелись силиконовые имплантанты, что в итоге привело к кумуляции эффекта и значительному повышению проявления системных реакций [7].

Со стороны местных реакций важно обращать внимание на появление подкожных узелков после инъекций гиалуроновой кислоты. Подкожные фиброзные узелки являются одним из вариантов реакций организма на введенный продукт, однако существует вероятность образования поздних подкожных гранулем, который крайне важно дифференцировать с обычными фиброзными узелками. Так гистологическая картина гранулематозных узелков у пациентов с развитием ASIA чаще всего выявляет 
гранулематозные реакции по типу инородного тела, окруженного эпителиоидными клетками с лейкоцитарной и лимфоидной инфильтрацией [8]. Особо важно всегда помнить, что гранулематозная реакция сообщает нам о гиперэргеческом ответе и повышенном дальнейшем риске развития ASIA $[9,10]$.Также при исследовании пациентов с предположительно грамулематозными поздними узелками, биопсия показали хроническую продуктивную воспалительную реакцию, которая у некоторых лиц сохранялась даже спустя 11 месяцев после лечения. Анализ сыворотки крови этих пациентов показал наличие антител против Рестилайна и/или Hylaform в виде IGA, E [11].На сегодняшний день уже многие авторы приходят к выводу, что гиалуроновая кислота способна выступать в роли адъюванта, провоцирую развития аутоиммунного воспалительного синдрома[12,13].

$$
* * *
$$

1. Shoenfeld Y., Agmon-Levin N. 'ASIA'-autoimmune/inflammatory syndrome induced by adjuvants. Journal of autoimmunity. - 2011. - T. 36. - №. 1. - C. 4-8.

2. Agmon-Levin N., Hughes G. R. V., Shoenfeld Y. The spectrum of ASIA:"Autoimmune (Autoinflammatory) Syndrome induced by Adjuvants'. - 2012. C. 3-5.

3. Бомфорд, Р. Адъюванты / Р. Бомфорд // Биотехнол. клеток животных - М., 1989. - Т. 2 - С. 264-280.

4. Javierre BM, Hernando H, Ballestar E. Environmental triggers and epigenetic deregulation in autoimmune disease. Discov. Med. -2012 - T. 12. - №. 68. - C. 535-545.

5. Glycosaminoglycans in autoimmunity. Hansen C 1, Otto E , Kuhlemann K , Förster G , Kahaly GJ Clinical and Experimental Rheumatology. 1996, 14 Suppl 15: S59-67.

6. Watad A. et al. The autoimmune/inflammatory syndrome induced by adjuvants (ASIA)/Shoenfeld's syndrome: descriptive analysis of 300 patients from the international ASIA syndrome registry //Clinical Rheumatology. -2017 . - C. 1-11.

7. Delayed immune-mediated adverse effects related to hyaluronic acid and acrylic hydrogel dermal fillers: clinical findings, longterm follow-up and review of the literature/ JAlijotas-Reig, V Garcia-Gimenez, JEADV 2008, 22, 150-161 Journal compilation (C) 2007 European Academy of Dermatology and Venereology.

8. Lemperle G, Morhenn VB, Charrier U. Human histology and persistence of various injectable filler substances for soft tissue augmentation. Aesthetic Plast Surg. 2003;27(5):354-367

9. Christensen L, Breiting V, Janssen M, Vuust J, Hogdall E. Adverse reactions to injectable soft tissue permanent fillers. Aesthetic Plast Surg. 2005;29(1):34-48

10. Ghislanzoni M, Bianchi F, Barbareschi M, Alessi E. Cutaneous granulomatous reaction to injectable hyaluronic acid gel. Br J Dermatol. 2006;154(4):755-758

11. Micheels P. Human Anti-Hyaluronic Acid Antibodies: Is it Possible? //Dermatologic surgery. - 2001. - T. 27. - №. 2. - C. 185-191.

12. Andre P, Lowe NJ, Parc A, Clerici TH, Zimmermann U. Adverse reactions to dermal fillers: a review of European experiences. J Cosmet Laser Ther 2005; 7 : 171-176.

13. Duffy DM. Complications of fillers: overview. DermatolSurg 2005; 31: 1626-1633.

\section{Кузнецов С.И., Овсянникова В.В. Метаболическая терапия у больных артериальной гипертензией}

Воронежский государственный медицинский университет им.Н.Н. Бурденко» Министерства Здравоохранения РФ (Россия, Владивосток)

doi:10.18411/spc-15-11-2017-05

idsp: 000001:spc-15-11-2017-05

Распространенность артериальной гипертензии (АГ) в европейской популяции колеблется от 35 до 47 \% и постоянно растет. Распространенность частоты выявления АГ увеличивается с возрастом. В связи с этим растет смертность от осложнений, которые возникают из-за прогрессирования АГ во всех возрастных категориях.

Процесс старения сопровождается ростом заболеваемости сопутствующей патологии на фоне АГ. У таких пациентов, как правило, имеется несколько сопутствующих заболеваний, как почечная недостаточность, хронические обструктивные заболевания легких, сахарный диабет, анемия и другое.

В последние годы доказана роль метаболических нарушений и свободно радикальных реакций в патогенезе дисфункции эндотелия при АГ. 
В этой связи одной из проблем является профилактика последствий гипоксии и оксидантного стресса в сосудах, как постоянной составляющей патологических процессов, как в миокарде, так и в головном мозге.

Дефицит энергии, являющийся основой любой формы гипоксии, приводит к ацидозу, активации свободнорадикального окисления, нарушению функций мембран клеток. Поэтому большое значение в медикаментозной профилактике развития осложнений является защита клеток и их восстановление для нормального функционирования.

С этой целью целесообразно применение антигипоксантов и антиоксидантов средств, оптимизирующих энергообменные процессы в клетках и улучшающих функциональную активность.

К данному классу относится этилметилгидроксипиридина сукцинат. Он обуславливается антиоксидантной активностью - 3-оксипиридинов и антигипоксическим действием - сукцината. Препарат снижает потери АТФ в ишемизированных клетках и активирует процесс окислительного фосфорилирования, а это приводит к повышению сократительной активности миокарда и раннему восстановлению функций головного мозга.

Также есть данные о способности улучшать микроциркуляцию и ингибировать агрегацию тромбоцитов в организме. В результате чего, применение этилметилгидроксипиридина сукцината способствует повышению устойчивости организма к дефициту кислорода и снижает риск постишемических нарушений, что делает назначение препарата актуальным при АГ [3].

Цель работы - изучить динамику фракции укорочения (ФУ) и фракции выброса (ФВ) левого желудочка (ЛЖ) этилметилгидроксипиридина сукцинат в комплексной терапии у больных с АГ.

\section{Материал и методы}

В исследовании продолжительностью 6 месяцев были включены 30 пациентов с АГ до 2 степени. В основную группу были включены 15 пациентов (7 мужчин и 8 женщин), в группу сравнения - 15 пациентов (9 мужчин и 6 женщин). Средний возраст пациентов основной группы составил 56,21 \pm 6,54 года, группы сравнения 58,32 $\pm 7,31$ года.

Критериями исключения из исследования явились: инфаркт миокарда, полная блокада левой и правой ножек пучка Гиса, перманентная форма фибрилляции и трепетания предсердий, кардиомиопатии (дилатационная, гипертрофическая, рестриктивная), гемодинамически значимые клапанные пороки сердца, сопутствующие хронические заболевания в стадии обострения или декомпенсации, онкологические заболевания, дыхательная недостаточность II - III степени, искусственный водитель ритма, постоянный прием других групп препаратов, кроме ингибиторов АПФ и блокаторов кальциевых каналов, отказ пациента от проводимого лечения.

Все группы пациентов были сопоставимы по полу, возрасту, степени АГ, приему лекарственных препаратов.

Начальная доза этилметилгидроксипиридина сукцината составила 250 мг 3 раза в день в течение 1 месяца, затем 125 мг 3 раза в день в течение 5 месяцев. Длительность участия каждого пациента в исследовании составила 6 месяцев. В схемы терапии включались ингибиторы ангиотензинпревращающего фермента, блокаторы кальциевых каналов. Группы больных были сопоставимы по полу, возрасту, длительности и тяжести АГ, характеру базисной терапии. Производился контроль ФУ и ФВ по данным Эхо-КГ в начале исследования и через 6 месяцев в сравнении.

Результаты исследования обработаны с использованием пакета прикладных программ SPSS, версия 10,0. Данные представлены в средних арифметических значениях с указанием стандартных отклонений. Достоверность различий оценивали по критерию Вилкоксона. Различия считали достоверными при $\mathrm{p}<0,05$. 


\section{Результаты исследования.}

Побочным явлением считали любое нежелательное изменение состояния пациента, отличное от состояния перед началом лечения, связанное или не связанное с исследуемым препаратом или препаратами стандартной терапии. Такие пациенты исключались из исследования и их данные не учитывались.

Согласно представленным данным, основная группа и группа сравнения сопоставимы по фракции укорочения (1-я группа: ФУ 28,85 $\pm 1,92 \%, 2$-я группа: ФУ $27,35 \pm 1,72 \%)$ и ФВ ЛЖ (1-я группа: ФВ 56,35 $\pm 1,14$ \%; 2-я группа: ФВ 57,85 $\pm 1,84$ $\%)$ в день начала исследования по данным Эхо-КГ. На фоне терапии через 6 месяцев отмечена положительная динамика вышеуказанных показателей в группе сравнения.

У пациентов основной группы на фоне лечения через 6 месяцев наблюдения отмечены достоверное снижение систолического артериального давления $(\mathrm{p}<0,05)$, снижение диастолического артериального давления $(\mathrm{p}<0,05)$ в сравнение с группой сравнения.

Через 6 месяцев наблюдения в основной группе получено достоверное увеличение ФУ ЛЖ $(36,85 \pm 1,42 \%, \mathrm{p}<0,05)$ и достоверное увеличение ФВ ЛЖ $(65,78$ $\pm 2,84 \%, \mathrm{p}<0,05)$, а в группе сравнения - ФУ $(28,62 \pm 1,34 \%, \mathrm{p}>0,05)$ и ФВ $(56,96 \pm$ $1,74 \%, \mathrm{p}>0,05)$ остались такими же, как и в первый день исследования.

\section{Заключение.}

Включение этилмедилгидроксипиридина сукцината дополнительно к традиционной гипотензивной терапии в дозах: 250 мг 3 раза в день в течение 1-го месяца, затем 125 мг 3 раза в день в течение 6 месяцев у больных с АГ до 2 степени приводит достоверному улучшению сократительной функции ЛЖ.

$$
* * *
$$

1. Андреева Н.Н. Экспериментальные и клинические аспекты применения мексидола при гипоксии. Мед альманах 2009; 4: 193-197.

2. Атрощенко Е.С. Пациент с хронической сердечной недостаточностью и сохраненной систолической функцией левого желудочка. Сердечная недостаточность 2007; 6: 297-300.

3. Белая О.Л., Байдер Л.М., Куроптева З.В., Фомина И.Г. Влияние мексидола на антиоксидантный статус у больных ишемической болезнью сердца. Клин мед 2005; 10: 57-60.

4. Оковитый С.В., Смирнов А.В. Антигипоксанты. Экспериментальная и клиническая фармакология. 2001; 64: 76-80.

5. Guidelines for the diagnosis and treatment of Chronic Heart Failure: full text (update 2005) The task force for the diagnosis and treatment of CHF of the European Society of Cardiology. Eur Heart J 2005; 26: 22: 2472 .

\section{Полушкина Н.А., Чиркова Н.В., Зубкова Т.В., Адамян Г.Г., Бобешко М.Н. Проведение бактериологического исследования полости рта пациентов с сахарным диабетом при протезировании съемными конструкциями}

Воронежский государственный медицинский университет им.Н.Н. Бурденко» Министерства Здравоохранения РФ

(Россия, Владивосток)

doi:10.18411/spc-15-11-2017-06

idsp: 000001:spc-15-11-2017-06

Сахарный диабет является огромной социальной проблемой, относящийся к приоритетам национальных систем здравоохранения практически всех стран мира. Более 230 миллионов человек в мире страдает сахарным диабетом. По данным эпидемиологических исследований в Российской Федерации в популяции населения сахарный диабет занимает 5-6\%, а около 90\% из этих больных составляют пациенты с сахарным диабетом 2 типа. В настоящее время реабилитация больных сахарным диабетом является сложной, многофакторной, комплексной проблемой. Считают, что диабет относится к факторам риска для развития поражения тканей пародонта. В то же 
время у больных пародонтитом в 10\% случаев выявляется сахарный диабет. Часто, впервые диагноз сахарного диабета устанавливает стоматолог, так как у многих больных пародонтитом нередко диагностируется его начальная стадия. Многочисленными исследованиями установлено, что у больных пародонтитом, на фоне сахарного диабета наблюдаются выраженные нарушения в микроциркуляторном русле пародонта: нарушение проницаемости кровеносных капилляров, повреждение базальной мембраны и эндотелиоцитов кровеносных капилляров. Это оказывает существенное влияние на трофику тканей пародонта, способствуя прогрессированию в них воспалительных и дистрофических процессов.

Для полости рта характерна определенная микрофлора с установленным качественным и количественным составом микроорганизмов. Постоянство микрофлоры поддерживается за счёт нормального функционирования слюнных желёз, слизистой оболочки, а также антагонистических взаимоотношений между микроорганизмами посредством феномена «бактериального взаимодействия».

Гипергликемия, микроангиопатия, а вследствие этого нарушение функции слюнных желёз, изменения в иммунной системе, генерализованные поражения твёрдых тканей зубов и пародонта способствуют ухудшению гигиены полости рта. Происходит увеличение численности условно-патогенных и патогенных микроорганизмов и уменьшение представителей нормофлоры, что является причиной дисбиоза полости рта.

Проведённые ранее бактериологические исследования показали, что у больных сахарным диабетом в полости рта наиболее часто встречаются условнопатогенные микроорганизмы с преобладанием пародонтопатогенной и грибковой микрофлоры, представленной ассоциациями дрожжевых грибов рода Candida. Самым распространённым проявлением дисбиоза полости рта при сахарном диабете является кандидоз. Наличие одновременно сахарного диабета и кандидоза может достигать 30$100 \%$.

Современный анализ влияния съемных протезов на ткани протезного ложа основан, как правило, на этиологических факторах развития побочных явлений при пользовании съемными протезами и направлен на достижение максимальной биологической совместимости протеза с тканями полости рта, которые возникают под воздействием определенных факторов:

- токсичности конструкционных материалов и аллергии к ним;

- механического раздражения;

- под микробным воздействием;

- при нарушении местного и общего иммунитета.

На современном этапе развития ортопедической стоматологии значительно возросли требования к базисным материалам, качество которых в значительной степени определяет функциональную ценность съемных зубных протезов. На данный момент 98 \% пластиночных протезов, используемых при ортопедическом лечении больных, изготавливаются из акриловых полимеров. Однако, у пациентов, пользующихся съемными протезами из акриловых пластмасс, возникали изменения со стороны тканей протезного ложа: развивался оральный кандидоз, для лечения которого авторами предлагалось множество средств. Для изготовления базисов съемных пластиночных протезов получили широкое применение эластичные материалы. Было доказано, что их применение приводит к снижению количества осложнений, возникающих при пользовании съемными пластиночными протезами.

В клинике ортопедической стоматологии было обследовано и проведено ортопедическое лечение 60 пациентов по поводу полного и частичного отсутствия зубов на верхней и нижней челюстях. Исследуемые пациенты были распределены на четыре группы по 15 человек. Изучены результаты видовой принадлежности бактерий в исследуемом материале со слизистой оболочки протезного ложа у пациентов первой 
группы, которым были изготовлены съемные протезы с базисом из акриловой пластмассы «Фторакс» (табл.1).

Таблийа 1

Оченка полученных результатов бактериологического исследования у пацичентов первой группь

\begin{tabular}{|c|c|c|c|}
\hline Микроорганизмы & $\begin{array}{c}\text { День фиксации } \\
\text { протезов }\end{array}$ & $\begin{array}{c}\text { Через 10 дней } \\
\text { после фиксации протезов }\end{array}$ & $\begin{array}{c}\text { Через 1 месяц } \\
\text { после фиксации протезов }\end{array}$ \\
\hline E.coli & $26,3 \%\left(10^{3}-10^{5}\right)$ & $37,9 \%\left(10^{5}-10^{6}\right)$ & $37,86 \%\left(10^{4}-10^{6}\right)$ \\
\hline Neisseria & $15,3 \%\left(10^{3}-10^{4}\right)$ & $15,3 \%\left(10^{3}-10^{5}\right)$ & $14,1 \%\left(10^{3}-10^{7}\right)$ \\
\hline Candida albicans & $20,5 \%\left(10^{3}-10^{4}\right)$ & $48,4 \%\left(10^{2}-10^{7}\right)$ & $48,6 \%\left(10^{3}-10^{5}\right)$ \\
\hline St. Aureus & $43,6 \%\left(10^{2}-10^{5}\right)$ & $55,48 \%\left(10^{3}-10^{5}\right)$ & $55,48 \%\left(10^{3}-10^{7}\right)$ \\
\hline Str. Epidermidis & $7,76 \%\left(10^{3}-10^{5}\right)$ & $6,56 \%\left(10^{3}-10^{6}\right)$ & $6,54 \%\left(10^{3}-10^{5}\right)$ \\
\hline Ent. Faecalis & $17,2 \%\left(10^{3}-10^{5}\right)$ & $16,78 \%\left(10^{3} 10^{5}\right)$ & $17,31 \%\left(10^{3}-10^{6}\right)$ \\
\hline Str. Piogenes & $13,7 \%\left(10^{2}-10^{4}\right)$ & $15,67 \%\left(10^{3}-10^{5}\right)$ & $15,58 \%\left(10^{5}-10^{6}\right)$ \\
\hline
\end{tabular}

Во вторую группу входили пациенты, которым были изготовлены протезы с базисом из КХС. Обнаружено усиление роста патогенной и условно-патогенной флоры через 10 дней и 1 месяц наблюдения (табл.2).

В третьей группе, пациенты которой пользовались съемными протезами с базисом из термопластического полимера отмечалось снижение роста патогенной и условно-патогенной флоры через 10 дней и 1 месяц, что отражено в таблице 3.

Таблийа 2

Оченка полученных результатов бактериологического исследования у пациентов второй группь

\begin{tabular}{|c|c|c|c|}
\hline Микроорганизмы & $\begin{array}{c}\text { День фиксации } \\
\text { протезов }\end{array}$ & $\begin{array}{c}\text { Через 10 дней } \\
\text { после фиксации протезов }\end{array}$ & $\begin{array}{c}\text { Через 1 месяц } \\
\text { после фиксации протезов }\end{array}$ \\
\hline E. coli & $27,2 \%(102-106)$ & $30,8 \%(104-106)$ & $30,7 \%(104-106)$ \\
\hline Neisseria & $13,3 \%(102-104)$ & $13,5 \%(103-106)$ & $11,5 \%(103-106)$ \\
\hline Candida albicans & $18,15 \%(102-105)$ & $46,7 \%(103-107)$ & $44,9 \%(103-105)$ \\
\hline St. Aureus & $40,1 \%(102-104)$ & $53,7 \%(103-107)$ & $45,3 \%(104-106)$ \\
\hline Str. Epidermidis & $8,79 \%(102-104)$ & $5,55 \%(103-106)$ & $6,65 \%(103-106)$ \\
\hline Ent. Faecalis & $18,18 \%(103-106)$ & $17,45 \%(102-105)$ & $18,21 \%(103-107)$ \\
\hline Str. Piogenes & $13,39 \%(103-107)$ & $13,54 \%(104-106)$ & $13,55 \%(103-106)$ \\
\hline
\end{tabular}

Таблица 3

Оченка полученных результатов бактериологического исследования у пачиентов третьей группь

\begin{tabular}{|c|c|c|c|}
\hline Микроорганизмы & $\begin{array}{c}\text { День фиксации } \\
\text { протезов }\end{array}$ & $\begin{array}{c}\text { Через 10 дней } \\
\text { после фиксации протезов }\end{array}$ & $\begin{array}{c}\text { Через 1 месяц } \\
\text { после фиксации протезов }\end{array}$ \\
\hline E.coli & $32,79 \%(104-106)$ & $25,68 \%(105-105)$ & $3,16 \%(103-106)$ \\
\hline Neisseria & $8,88 \%(103-105)$ & $3,81 \%(102)$ & не высевалось \\
\hline Candida albicans & $32,14 \%(103-106)$ & $27,29 \%(102-104)$ & $2,21 \%(103-106)$ \\
\hline St. Aureus & $36,78 \%(103-107)$ & $26,41 \%(103-105)$ & $2,29 \%(103-104)$ \\
\hline Ent. faecalis & $17,29 \%(102-105)$ & $12,17 \%(103-104)$ & $1,13 \%(103-105)$ \\
\hline Str. epidermidis & $17,1 \%(102-105)$ & $15,7 \%(103-105)$ & $1,48 \%(103-105)$ \\
\hline Klebsiella & $3,21 \%(103-104)$ & $3,38 \%\left(10^{2}-105\right)$ & не высевалось \\
\hline Str. piogenes & $8,39 \%(104-106)$ & $7,98 \%(103-106)$ & не высевалось \\
\hline
\end{tabular}

Таким образом, все полученные значения у пациентов четвертой группы со съемными протезами с базисом из термопластического полимера и с комплексным лечением, характеризующимся применением антибактериальной пленки-повязки «ППА-РАД» для профилактики и лечения тканей пародонта и «Кальцемин Адванс» приближались по своим данным к результатам исследования третьей группы (табл.4). 
Таким образом, у пациентов, которые пользовались съемными протезами, из термопластического полимера и с комплексным лечением, характеризующимся применением антибактериальной пленки - повязки «ППА-РАД» для профилактики и лечения тканей пародонта и «Кальцемин Адванс» было отмечено отсутствие осложнений, таких как кандидоз, протезный стоматит, что свидетельствовало о комфортной адаптации к ним.

Таблица 4

Оченка полученных результатов бактериологического исследования у паичиентов четвертой группь

\begin{tabular}{|c|c|c|c|}
\hline Микроорганизмы & $\begin{array}{c}\text { День фиксации } \\
\text { протезов }\end{array}$ & $\begin{array}{c}\text { Через 10 дней } \\
\text { после фиксации протезов }\end{array}$ & $\begin{array}{c}\text { Через 1 месяц } \\
\text { после фиксации протезов }\end{array}$ \\
\hline E.coli & $32,58 \%(103-107)$ & $25,41 \%(103-106)$ & $3,5 \%(103-104)$ \\
\hline Candida albicans & $31,8 \%(102-106)$ & $27,21 \%(103-107)$ & $3,2 \%(102-105)$ \\
\hline Neisseria & $8,3 \%(103-105)$ & $3,54 \%(102-105)$ & не высевалось \\
\hline St.aureus & $36,12 \%(103-105)$ & $26,40 \%(103-106)$ & $2,30 \%(103-106)$ \\
\hline Str. Epidermidis & $17 \%(103-106)$ & $15,1 \%(103)$ & $1,5 \%(103-106)$ \\
\hline Ent. Faecalis & $16,4 \%(103-105)$ & $12,6 \%(103-104)$ & $1,12 \%(103)$ \\
\hline Klebsiella & $3,5 \%(103)$ & $3,46 \%\left(10^{2}\right)$ & не высевалось \\
\hline Str. Piogenes & $8,4 \%(104-105)$ & $7,3 \%(103-104)$ & не высевалось \\
\hline Str. Pneumonia & $3,8 \%(104)$ & $2,1 \%(103)$ & не высевалось \\
\hline
\end{tabular}

$* * *$

1. Анализ воспалительно-дистрофических процессов в тканях полости рта у больных сахарным диабетом 2 типа / Полушкина Н.А., Морозов А.Н., Чубаров Т.В., Вечеркина Ж.В. // Системный анализ и управление в биомедицинских системах.- 2016. - Т.15, № 1. - С.18-21.

2. Попкова А.С. Сахарный диабет 2 типа в контексте эволюционной медицины / А.С., Попкова, А.М. Василенко // Системный анализ и управление в биомедицинских системах. - 2017. - Т. 16, № 1. C.54-59.

3. Чиркова Н.В. Сравнительный анализ применения базисных материалов в ортопедической стоматологии / Н.В. Чиркова // Системный анализ и управление в биомедицинских системах. 2010.-T. 9, № 3. - С.531 - 535.

4. Голубев Н.А., Чиркова Н.В., Полушкина Н.А., Плотникова И.Е., Бобешко М.Н. Современные аспекты гигиены полости рта у больных пользующихся съемными протезами // Системный анализ и управление в биомедицинских системах. - 2016. - Т.15, № 2. - С. 248-250.

\section{Трошкова В.Н., Давыдова Э.К., Байда К.Ю., Трошков А.М. \\ Разработка универсального мобильного локализатора с очистителем воздуха для первичной обработки огнестрельных ранений конечностей}

Ставропольский краевой клинико-диагностичесий центр

(Россия, Ставрополь)

Буденовская районная больница

(Россия, Буденовск)

Ставропольский государственный медиџинский университет

(Россия, Ставрополь)

МП НПО «ООО ИТ-Видео»

(Россия, Ставрополь)

doi:10.18411/spc-15-11-2017-07

idsp: 000001:spc-15-11-2017-07

\section{Аннотация}

В статье проведен краткий анализ огнестрельных ранений конечностей, составлена классификация, сформулирована задача оперативной помощи, предложен универсальный мобильный локализатор с очистителем воздуха для первичной обработки огнестрельных ранений конечностей. 
Ключевые слова: Огнестрельные ранения конечностей, мобильный локализатор с очистителем воздуха, схемотехническое устройство, наддув.

При этой категории травм возникает много проблем, решение которых не всегда простое. Ранения сопровождаются массивной кровопотерей, условия заживления ран хуже, чем ран на верхней конечности. Раны часто осложняются инфекцией. Большие затруднения представляет закрытие кожного дефекта голени. Внутрикостный остеосинтез при огнестрельных переломах бедра в настоящее время практически не производят из-за высокого процента развивающихся вследствие этого гнойных осложнений, остеомиелитов, высокой инвалидизации раненых. Огнестрельные ранения голени отличаются также и тем, что при них часто травмированы окружающие кость мягкие ткани, включая сосудисто-нервные образования, вторичными костными осколками. После тщательно проведенной хирургической обработки и сопоставления костных отломков. Тяжелые повреждения мягких тканей и кости при огнестрельных ранениях конечностей даже в мирное время, в силу особенностей течения раневого процесса и сложности лечения данной патологии, возводят данную проблему в ранг актуальнейших. Ранения мирного времени связаны с бытовыми и социальными конфликтами, преступной деятельностью и неосторожным обращением с огнестрельным оружием. Несомненно, характер повреждения тканей находится в прямой связи с баллистикой ранящего снаряда и величиной кинетической энергии, воздействующей на организм. Поэтому огнестрельные раны от выстрела в упор, с близкого расстояния, отличаются большими разрушениями, чем раны, полученные от снаряда на излете. Особую группу составляют повреждения, возникающие при взрывной травме, когда одновременное действие нескольких травмирующих факторов вызывает массивные разрушения тканей, вплоть до отрыва конечностей. Подобные травмы всегда сопровождаются тяжелым геморрагическим шоком. «Главный военный клинический госпиталь» привел диагнозы, с какими туда поступают бойцы антитеррористических подразделений: множественные огнестрельные осколочные и пулевые ранения головы, шеи, грудной клетки, конечностей, баротравмы, тяжелые ушибы головного мозга. Анализ ранений конечностей показал следующую классификацию, представленную в таблице 1

Таблица 1

Классификация огнестрельных ранений конечностей по материалам ведения боевых действий в Демократической республике Афганистан.

\begin{tabular}{|c|c|}
\hline $\begin{array}{l}\text { По отношению к } \\
\text { полости сустава }\end{array}$ & сквозные, слепые и касательные \\
\hline $\begin{array}{c}\text { По виду ранящего } \\
\text { снаряда: }\end{array}$ & пулевые, осколочные, минно-взрывные, вторичными снарядами. \\
\hline По характеру ранения: & проникающие, непроникающие, сквозные, слепые, касательные. \\
\hline $\begin{array}{l}\text { По степени } \\
\text { повреждения мягких } \\
\text { тканей и кости: }\end{array}$ & $\begin{array}{l}\text { точечная рана мягких тканей без повреждения кости; рана мягких тканей, не } \\
\text { требующей хирургической обработки, с небольшим повреждением кости; } \\
\text { обширный дефект мягких тканей со значительным повреждением костей. }\end{array}$ \\
\hline $\begin{array}{l}\text { По характеру } \\
\text { внутрисуставных } \\
\text { повреждений }\end{array}$ & $\begin{array}{c}\text { - переломы с незначительными или умеренными повреждениями костей: типы B, } \\
\text { C1, С2 поклассификации М. Muller с соавторами (Ітип по R.B.Gustillo); } \\
\text { - переломы с тяжелыми повреждениями костей: полные многооскольчатые } \\
\text { внутрисуставные переломы с дефектами и повреждениямикостной и хрящевой } \\
\text { тканей, с высоким рискомнекроза кости и развития контрактур - типы В3и C } \\
\text { переломов головки бедренной кости, а также переломы типа C3 других крупных } \\
\text { суставовконечностей (IІтип по R.B. Gustillo). }\end{array}$ \\
\hline $\begin{array}{c}\text { По сопутствующим } \\
\text { повреждениям: }\end{array}$ & с повреждением крупных кровеносных сосудов; с повреждением нервов. \\
\hline
\end{tabular}


Клинические проявления огнестрельных ранений суставов зависят от вида сустава и характера повреждений. При иных равных условиях наиболее тяжелая общая симптоматика наблюдается при ранениях тазобедренного, коленного и плечевого суставов. При ранениях скоростными боеприпасами, как пулями, так и осколками, типична их фрагментация после контакта с костными образованиями сустава. В дальнейшем эти осколки играют роль инородных тел, что существенно осложняет и утяжеляет послеоперационное течение. Встречаются относительно легкие ранения суставов, когда пуля преимущественно низкоскоростная или осколок, проникает в полость сустава и застревает в костной структуре. Клиническая картина складывается из общих и местных симптомов. Для местных проявлений типичны ограничение подвижности, резкая болезненность при мельчайшем движении, увеличение размера суставов, в итоге нарастающего отека и гемартроза. При обширных дефектах мягких тканей в области сустава, часто отмечается истечение синовиальной жидкости. Общее состояние пострадавшего с огнестрельным повреждением сустава может быть очень тяжелым, сопровождаться шоком. Следует иметь в виду, что шок при ранениях тазобедренного или коленного сустава возникает в 2-2,5 однажды чаще, чем при ранениях суставов плеча или предплечья. Если одномоментно с повреждением костных структур сустава повреждаются нервы или магистральные кровеносные сосуды, опасность стремительно нарастающих осложнений в виде анаэробной инфекции, гнилостной инфекции, ишемической гангрены конечности весьма велика. Повреждения крупных кровеносных сосудов при огнестрельных повреждениях суставов верхних конечностей отмечается в $3 \%$ случаев, нижних конечностей - 4,5\%. Первое место в этих вариантах занимают коленный, локтевой и голеностопный суставы. Периферические нервы, напротив, чаще (около 12\%) страдают при ранениях суставов верхней конечности; при ранениях тазобедренного, коленного и голеностопного суставов частота ранений нервов отмечаются около 6\%[2,6].

Исходя из представления ранений конечностей, их первичной обработки в динамике функционирования боевых действий, необходимо добиться повышения оперативности оказания первичной медицинской помощи, нейтрализации соприкосновения грязного воздуха и окружающих предметов и скорейшей транспортировки в специализированные лечебные учреждения.

С этой целью в лабораториях МП НПО « ООО ИТ-ВИДЕО» г. Ставрополь проектируется универсальный мобильный локализатор с очистителем воздуха для первичной обработки огнестрельных ранений конечностей. Для создания замкнутого пространства локализатора необходим выбор ткани, рисунок 2

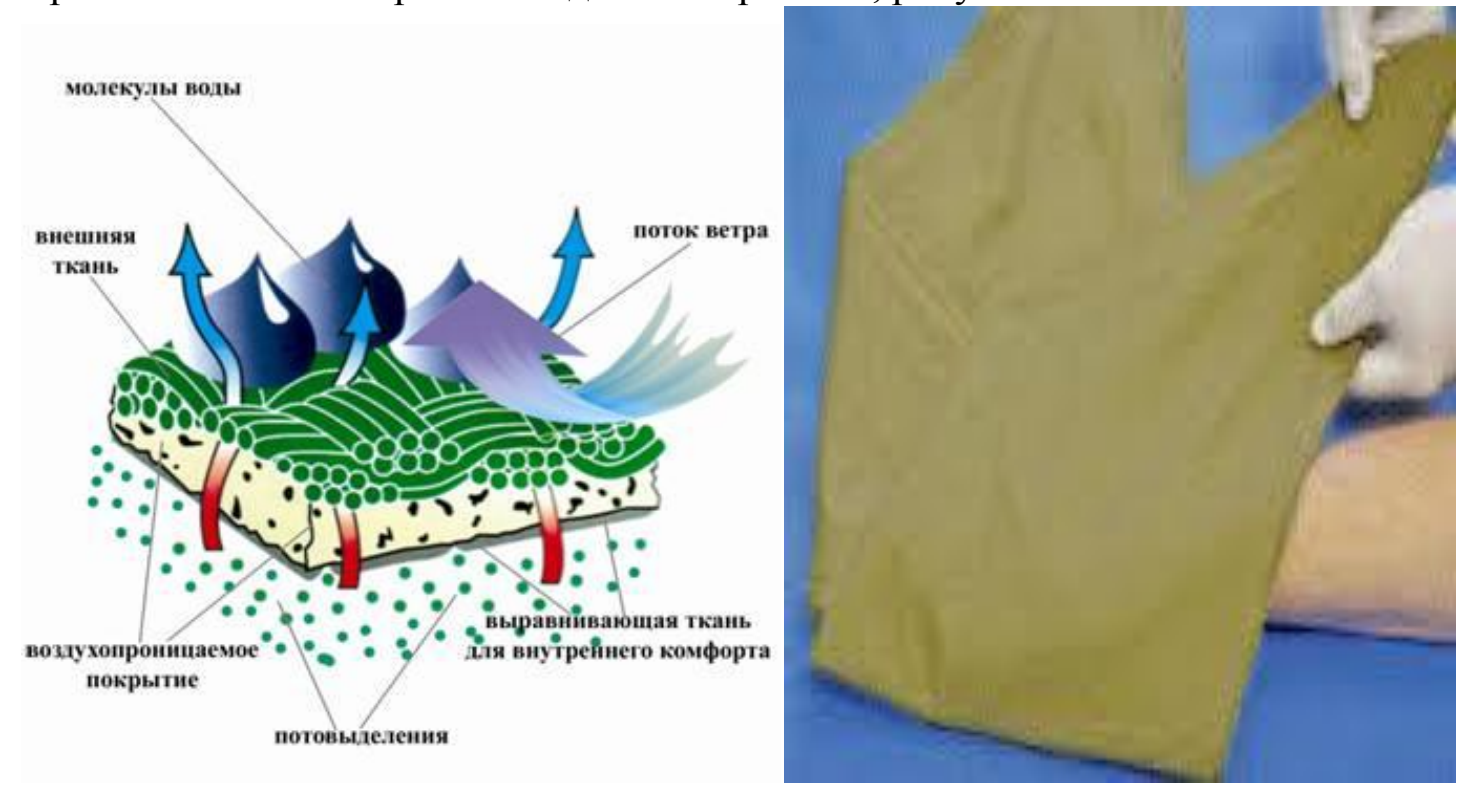

Рисунок 2 - Выбор ткани 
Требование к ткани:

- защитная маскировка (летняя и зимняя);

- высокая прочность;

- влагозащищенная;

- поддержание сжатого воздуха;

После выбора соответствующей ткани приступаем к проектировки универсального мобильный локализатора с очистителем воздуха для первичной обработки огнестрельных ранений конечностей, структурное схемотехническое устройство представлено на рисунке 3.

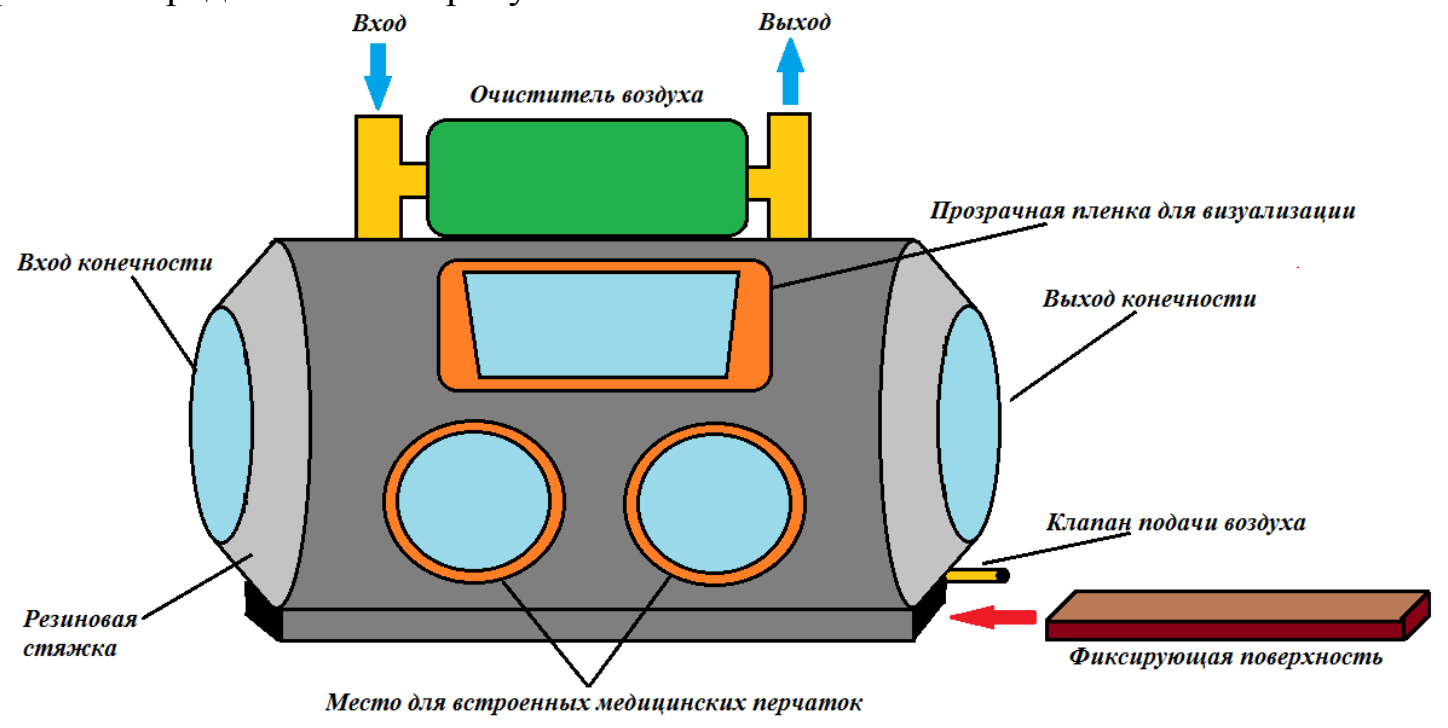

Рисунок 3 - Структурное схемотехническое устройство первичной обработки огнестрельных ранений конечностей.

На рисунке 3 представлен состав оборудования: 1. Локализатор надувной (наддув осуществляется через клапан подачи воздуха). 2. Очиститель воздуха (потребляет окружающий воздух, закачивает в локализатор очищенный воздух) представлен на рисунке 4. 3. Встроенные медицинские хирургические перчатки. 4. Резиновые стяжки для обхвата пораженной конечности. 5. Прозрачная пленка для визуального наблюдения локализированной раны. 6. Место и поверхность для фиксации конечности.

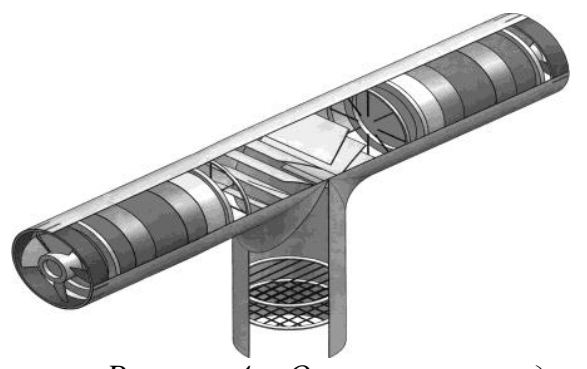

Рисунок 4 - Очиститель воздуха

Очиститель содержит фильтр грубой очистки из разноименно заряженных токопроводящих фильтрующих элементов, между которыми установлен высокопористый диэлектрический фильтрующий элемент, двухсекционное зарядное устройство с разноименными коронами, коронирующие и некоронирующие электроды которого снабжены токопроводящими фильтрующими элементами. Управление схемотехническим устройством первичной обработки огнестрельных ранений конечностей предлагается осуществлять с устройства управления специализированной медицинской сумки, представленной на рисунке5. 


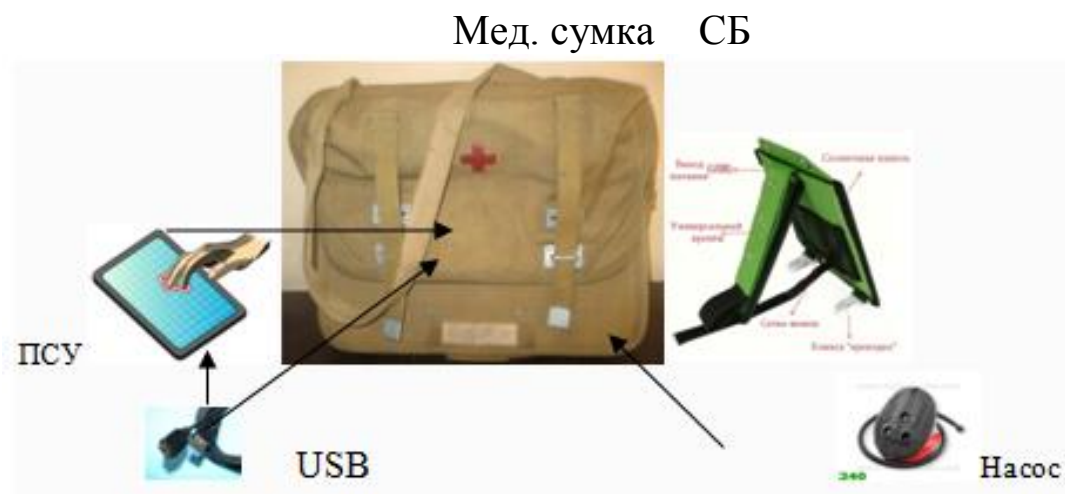

Рисунок 5 - Специиализированная медицинская сумка с устройством управления

Состав устройства управления:

- ПСУ (плата с сенсорным управлением);

- СБ (солнечная батарея) ;

- Разъемы и шнуры USB;

- Насос для накачки локализованной камеры.

Исходя из выше изложенного, разработан алгоритм действия медицинского специалиста по эксплуатации и применению универсального мобильного локализатора с очистителем воздуха для первичной обработки огнестрельных ранений конечностей. На поле боя осуществляется мониторинг санитарного состояния среди личного состава военнослужащих, при выявлении ранений медицинский специалист (санинструктор, фельдшер, врач) выдвигается в зону нахождения раненого. При диагностировании ранений конечностей достает из медицинской сумки мобильный локализатор, который одевает на конечность в области ранения, с помощью насоса осуществляет наддув камеры (в камеру заносятся необходимые инструменты и лекарства), устанавливается в специальный разъем очиститель воздуха (подключается СБ или элементы аккумуляторных батарей), который очищает загрязненный воздух. В этот период медицинский специалист проводит с помощью прозрачной пленки и встроенных медицинских перчаток необходимые действия. По окончанию необходимой обработки с помощью ПСУ и USB заносятся необходимая специализированная информациия на ОЗУ, которая встроена в прослойку камеры локализатора (например время, лекарства, и.т.д. специальным формализованным кодом с ПСУ). По окончанию всех неоходимых процедур отсоединяется очиститель воздуха закрываются клапана, которые поддерживают наддув камеры. Раненый готов к транспортировки ( при необходимости в дно камеры можно установить фиксирующую поверхность. Далее медицинский специалист может действовать по обстановке или проводить такие же действия с другим раненным (локализаторов в сумке может находится несколько штук).

Таким образом, оперативными действиями и с применением универсального мобильного локализатора с очистителем воздуха для первичной обработки огнестрельных ранений конечностей можно устранить гнойные процессы и поддерживать несколько часов очаг ранения в стерильном состоянии. В качестве дополнения можно установить микробактериоцидную лампочку во внутрь камеры локализатора.

$$
* * *
$$

1. Ахмедов Б.А., Тихилов Р.М. Оперативное лечение внутрисуставных огнестрельных повреждений крупных суставов конечностей // Травматология и ортопедия России, 2008, №2, С.5-13

2. Капустин Р.Ф., Гомбалевский Д.В. Огнестрельные ранения конечностей // Методические рекомендации, Минск, 2004 
3. Соломин, Л.Н. Основы чрескостного остеосинтеза аппаратом Г.А. Илизарова / Л.Н. Соломин. СПб.: МОРСАР АВ, 2005. - 544 с.

4. Шаповалов, В.М. Боевые повреждения конечностей: инфраструктура ранений и особенностей состояния раненых в период локальных войн / В.М. Шаповалов // Травматология и ортопедия России. - 2006. - № 2. - С. 301-302.

5. Шаповалов В.М. Аверкиев В. А. Современные принципы лечения огнестрельных ранений суставов конечностей на этапах медицинской эвакуации // «Состояние и перспективы развития военной травматологии и ортопедии» - труды ВМедА, том 248, С.Петербург, 1999, c.210-218

6. http://auno.kz/rentgenodiagnostika-zabolevanij-kostej/369-rentgenodiagno...

7. Gustilo, R.B. Problems in the management of type III (severe) open fractures: a new classification of type III open fractures / R.B. Gustilo, R.M. Mendoza, D.N. Williams // J. Trauma. - 1984. - Vol. 24. - P. 742.

8. Muller, M. The AO classification of fractures / M. Muller, S. Nasarin, P. Koch. - Berlin etc. :Springer_Verlag, 1987.

9. Трошков А.М., Трошков М.А. Концепция проектирования биометрической системы для управления допуском к информационным ресурсам. Научно-исследовательский журнал «Вестник СевКавГТИ» выпуск № 13, 2012.- 225 с.

10. Трошков А.М., Трошков М.А., Свидетельство о государственной регистрации программы для ЭВМ № 2012617031 «Информационная система аутентификации личности по биометрическим характеристикам». Заявка № 2012614575. Зарегистрировано в Реестре программ для ЭВМ 6 августа 2012.

11. Трошков А.М., Трошков М.А., Кондрашов А.В. Биометрические характеристики человека и их аутентификационные признаки - база создания защиты и ограничение доступа к информационным ресурсам АПК. Научно-практическая конференция «Вестник АПК Ставрополья» №3(3), 2011 $139 \mathrm{c}$.

\section{Фомина К.А., Чиркова Н.В., Вечеркина Ж.В., Калиниченко В.С., Кончакова В.В. Определение токсикологических показателей безопасности дезинфектанта для съемных зубных протезов из термопластических материалов}

Воронежский государственный медииинский университет им.Н.Н. Бурденко» Министерства Здравоохранения РФ (Россия, Владивосток)

doi:10.18411/spc-15-11-2017-08

idsp: 000001:spc-15-11-2017-08

В настоящее время большие достижения прослеживаются в лечении стоматологических заболеваний, имплантологии и превентивных мероприятиях заболеваний челюстно-лицевой области. Однако потребность в ортопедическом лечении съемными зубными протезами остается на высоком уровне, и с возрастом она только возрастает. По-прежнему в современном обществе использование съемных ортопедических конструкций можно отнести к категории доступных и востребованных видов ортопедической помощи. Большое значение при выполнении съемных зубных протезов играет выбор конструкционных материалов, так как проблема биоинертности занимает лидирующие позиции в клинике ортопедической стоматологии. В настоящее время российский стоматологический рынок предлагает широкий ассортимент термопластических полимеров для съемных конструкций зубных протезов. Данные материалы необычайно перспективные в стоматологии Термопластические материалы характеризуются биоинертностью для организма человека, так как не содержат остаточный мономер. Эта группа материалов обладает хорошей прочностью, гибкостью, устойчивостью к внешним воздействиям, легкостью, эластичностью и высокой эстетичностью. Технологические недостатки, которые связаны, в основном со сложностями окончательной обработки термопластов, влияющие на эстетичность и долговечность конструкции, в настоящее время сводятся к минимуму, благодаря использованию отечественных апробированных и положительно зарекомендовавших в практическом применении полировочных средств. Следует отметить, что в процессе эксплуатации, съемные протезы из термопластических полимеров нуждаются в профессиональном гигиеническом уходе. Во- первых, пациенты ввиду 
профессиональной некомпетентности довольно часто не разделяют понятия «очистки» зубных протезов и «дезинфекции»съемных ортопедических конструкций, во- вторых, не в полном объеме представляют значимость выполнения рекомендаций по уходу за зубными протезами, а этот фактор занимает немаловажное значение в вопросах продолжительности службы любой конструкции зубного протеза.

В результате научных исследований установлено, что предварительная очистка зубных протезов предполагает лишь удаление с поверхности базисного полимера мягких и твердых зубных отложений, слюны остатков пищи, пигментов без применения химических дезинфицирующих препаратов, но с использованием веществ, обладающих моющими свойствами, предназначенных для удаления загрязнения с базисного полимера. В качестве средств предстерилизационной очистки пациентами могут быть использованы специальные или зубные щетки, зубных пасты, гели. Доказано, что дезинфекция это мероприятия по уничтожению и снижению активности различных микроорганизмов и грибов с использованием жидких или растворимых средств и приборов. Анализ отечественной и зарубежной литературы показывает, что современные методы очистки и дезинфекции съемных протезов можно осуществлять с помощью механических, физических и химических средств. Следует отметить, что химическая дезинфекция протезов с базисом из термопластических полимеров является самым распространенным и доступным методом и предполагает снижение или гибель численности микроорганизмов за счет воздействия химических веществ. В настоящее время дезинфектанты выпускаются в таких формах, как жидкие концентраты, таблетки, гранулы, порошки, готовые формы применения, например рабочие растворы, бактерицидные салфетки, аэрозольные баллоны, лаки для обработки зубных протезов различных конструкций, как импортного, так и отечественного производства. Однако, многие формы при продолжительном использовании способны оказывать негативное влияние на акриловые, термопластические базисные полимеры съемных ортопедических конструкций, металлические части протезов, а согласно экспрессопросу клиницистов и тематических пациентов последние отдают предпочтения рабочим растворам отечественного производства при условии соответствия стандартам качества.

Известно, что без осуществления всех требований, предъявляемых к дезинфицирующим средствам, он не может быть рекомендован специалистами к использованию. Несомненно, главными условиями, которые обеспечивают целевую эффективность, являются способность уничтожать весь спектр микроорганизмов, обозначаемая, таким понятием, как надежность используемого дезинфектанта. Основой безопасности применяемого средства служит и контроль химических и физических средств, ученые вкладывают в данный критерий пожаро- и взрывоопасность, стабильность, их летучесть, а также биосовместимость. Одним из значимых критериев безопасности дезинфицирующих препаратов является, конечно же, оценка специфических эффектов воздействия на здоровье человека.

На кафедре пропедевтической стоматологии ВГМУ им. Н.Н. Бурденко, совместно с ООО «Целит» (г. Воронеж) был определен окончательный состав готового к применению дезинфицирующего раствора «Дентасептин» с содержанием 20\% серебряной воды для очищения съемных ортопедических конструкций с базисом из термопластического полимера. Все действующие активные компоненты данного дезинфектанта были подвержены тщательной оценке.

С целью возможности применения дезинфицирующего раствора «Дентасептин» с содержанием $20 \%$ серебряной воды нами было проведено его токсикологическое исследование в лаборатории профилактической стоматологии. Во - первых, было 
изучено аллергенное действие и кожно-резорбтивное действие «Дентасептин с ионами серебра». Аллергенность состава изучали на четырех кроликах с использованием конъюнктивальных проб. Местно-раздражающее действие оценивали на четырех морских свинках (методикой накожных аппликаций). Под верхнее веко правого глаза кроликам закапывали по одной капле готового водного раствора «щДентасептин с ионами серебра». В левый глаз этим же животным для контроля вносили по одной капле физраствора. Регистрация проводилась через 5 минут, 24 и 48 часов. При этом оценивали состояние слизистой оболочки глаза и век, наличие инъекции сосудов, секрецию слезы. Критерием отсутствия отрицательного воздействия раствора «Дентасептин» с содержанием $20 \%$ серебряной воды являлось то, что в течение всего периода наблюдения у кроликов изменений со стороны глаз не наблюдали.

Перед началом провокационных кожных проб методом аппликаций на морских свинках проводили сенсибилизацию их путем многократного нанесения на кожу раствора «Дентасептин» с содержанием $20 \%$ серебряной воды, а именно, ежедневно на выстриженный участок кожи морским свинкам наносили водные растворы в разведениях 1:1; 1:10 и 1:100. Во время инкубационного периода (14 день) на свежевыстриженный участок кожи наносили разрешающие дозы. В течение всего периода за морскими свинками вели наблюдение, проводили измерение температуры тела, толщины кожной складки на месте аппликации, определяли температуру на месте введения. Изменений в клиническом статусе животных и на месте аппликаций «Дентасептин» с содержанием 20\% серебряной воды не выявлено. Таким образом, Ответная реакция оценивалась нами отрицательно по таким критериям, как нормальная температура тела, неизменность толщины кожной складки на месте аппликации, отсутствие сильного изменения температуры на месте введения.

Проведенные токсикологические исследования показали, что исследуемый состав является нетоксичным химическим веществом, не обладает аллергенными, кожно-резорбтивными свойствами. На основании изученного становится очевидным, что раствор «Дентасептин» с содержанием $20 \%$ серебряной воды не токсичен и может применяться для дезинфекции съемных ортопедических конструкций из термопластических полимеров.

$$
* * *
$$

1. Голубева Л.А. Экспериментально - клиническое обоснование эффективности дезинфекции съемных пластиночных протезов раствором, содержащим ионы серебра: дис. ... канд. мед. наук. Воронеж, 2013. $140 \mathrm{c}$.

2. Голубев Н.А. Современные аспекты гигиены полости рта у больных пользующихся съемными протезами / Н.А. Голубев, Н.В. Чиркова, Н.А. Полушкина, И.Е. Плотникова, М.Н. Бобешко // Системный анализ и управление в биомедицинских системах. - 2016. - Т.15, №2. - С.248-250.

3. Медико-социальная значимость проблемы дезинфицирующей обработки съемных протезов у лиц пожилого возраста / К.А. Фомина, Н.В. Чиркова, Ж.В. Вечеркина, А.Н. Морозов, Т.А. Попова / Системный анализ и управление в биомедицинских системах.- 2016.- Т.15, № 4.-С.692-695.

4. Применение термопластических материалов в стоматологии: учебное пособие / И.Д. Трегубов [и др.]. - М.: Медицинская пресса, 2007. - 140 с.: илл.

5. Роль антисептической лечебно-профилактической жидкости во время стоматологического приема / Заидо Абдулкадер, А.Н. Морозов, Ж.В. Вечеркина, Н.В. Чиркова // Системный анализ и управление в биомедицинских системах. - 2014. - Т.13, №4. - С.847-849.

6. Рубцова Е.В. Изучение качества поверхности базисов зубных протезов из термопластических полимеров после окончательной обработки / Е.В. Рубцова [и др.] // Системный анализ и управление в биомедицинских системах. - 2017. - Т. 16, № 1. - С. 68-72.

7. Токсикологическая оценка нового раствора для дезинфекции съемных пластиночных протезов / Э.С. Каливраджиян, Л.Н. Голубева, Н.А. Голубев, Н.В. Чиркова, А.В. Подопригора // Российский стоматологический журнал.- Москва, 2013. - №1.-С.12-15. 


\section{Фролова А.В., Орлова М.М., Родионова Т.И. \\ Значение цитокинового ответа в развитии поражения сердечно-сосудистой системы при диффузном токсическом зобе}

ФГБОУ ВО «Саратовский ГМУ им. В.И. Разумовского»

(Россия, Саратов)

doi:10.18411/spc-15-11-2017-09

idsp: 000001:spc-15-11-2017-09

\section{Аннотация}

Целью исследования является оценка возможности влияния иммунологических изменений на формирование сердечно-сосудистых осложнений тиреотоксикоза путем определения уровня антител к рецептору тиретропного гормона (АТ-рТТГ), интерлейкинов 6,8,10 (ИЛ-6,8,10) и фактора некроза опухоли-альфа (ФНО - $\alpha)$ у пациентов с диффузным токсическим зобом (ДТЗ) и хронической сердечной недостаточностью $(\mathrm{XCH})$ и без нее. При обследовании 68 пациентов с ДТЗ, ХСН диагностирована у 38 больных (55,9\%), при этом 1 стадия - у 12 пациентов $(31,6 \%), 2 \mathrm{~A}$ стадия - у 19 (50\%) больных, 2Б стадия - у 7 (18,4\%) больных. Для проведения анализа пациенты разделены на 3 группы: 1 - без признаков ХCH, 2- с ХCH 1 стадии (так как клинические признаки, характерные для 1 стадии ХCH могут быть также симптомами тиреотоксикоза, данные больные выделены в отдельную группу), 3 - с ХСН 2А и 2Б стадии. Во всех 3 группах отмечено достоверное повышение уровней исследуемых цитокинов и АТ-рТТГ по сравнению с группой контроля. Развитие ХСН у пациентов с ДТЗ ассоциировано с повышением концентрации ИЛ-6, ИЛ-8 и ИЛ-10, также установлено, что прямой корреляции между уровнем АТ-рТТГ и ФНО- $\alpha$ с развитием поражения сердечно-сосудистой системы не выявлено.

Ключевые слова: диффузный токсический зоб, хроническая сердечная недостаточность, антитела к рецептору тиреотропного гормона, цитокины.

\section{Abstract}

The aim of the study is to assess the ability to influence immunological changes on the formation of cardiovascular complications of hyperthyroidism by determining the level of thyrotropin-receptor antibodies (TRAb), 6,8,10 interleukins (IL-6,8,10) and tumor necrosis factor-alpha (TNF - $\alpha$ ) in patients with Graves' disease (GD) and chronic heart failure (CHF) and without it. 68 patients were investigated with GD, CHF diagnosed in 38 patients $(55.9 \%)$, stage 1 - in 12 patients $(31.6 \%)$, stage $2 \mathrm{~A}$ - in $19(50 \%)$ patients, stage $2 \mathrm{~B}$ - in $7(18,4 \%)$ patients. For the analysis, patients were divided into 3 groups: 1 - with no signs of heart failure, 2 with CHF 1 stage (because the clinical signs characteristic of heart failure stage 1 can also be symptoms of hyperthyroidism, these patients were in separate group), 3 - CHF $2 \mathrm{~A}$ and step 2B. In all three patients groups showed a significant increase in the levels of cytokines and TRAb compared with the control group. The development of CHF in patients with Graves' disease is associated with increasing of IL-6, IL-8 and IL-10 concentration. Direct correlation between the level of TRAb, TNF - $\alpha$ and development of the cardiovascular complications in patients with GD have not been identified.

Key words: Graves disease, chronic heart failure, thyrotropin-receptor antibodies, cytokines.

\section{Введение}

Диффузный токсический зоб (ДТЗ) - это хроническое аутоиммунное заболевание, которое в $80 \%$ случаев служит причиной развития тиреотоксикоза [1]. Заболевание возникает в любом возрасте, но чаще всего у лиц от 20 до 40 лет, при этом женщины болеют в 7 раз чаще мужчин [2]. В 1978 году Р. Вольпе была доказана теория 
аутоиммунного происхождения данного заболевания, согласно которой в организме появляются форбидные («запрещенные») клоны Т-лифоцитов, которые в свою очередь стимулируют продукцию специфических антител В-лимфоцитами [3]. В настоящее время существуют неоспоримые данные о роли цитокинов в патогенезе ДТЗ. В дебюте заболевания отмечается повышение концентрации как провоспалительных (ИЛ-4,6,8, ФНО - $\alpha$ ), так и противовоспалительных цитокинов (ИЛ-10) [4,5,6]. Последнее десятилетие широко обсуждается значение данных иммунологических изменений в поражении сердечно-сосудистой системы при ДТЗ, однако, полученные авторами данные противоречивы [7]. В исследовании О.В. Серебряковой показана прямая взаимосвязь между концентрацией ИЛ-1, ИЛ-4 и ФНО- $\alpha$ с развитием тяжелого тиреотоксикоза и тиреотоксической кардиомиопатии [8]. Значительная роль ИЛ-6 в формировании и прогрессировании ХСН при ДТЗ отмечена И.К. Латогуз [9]. При этом в работе Т.В. Гома не установлено достоверных различий между уровнем ИЛ-8, ИЛ-10, ФНО- $\alpha$ в группе пациентов с ДТЗ, осложненным ХСН и без нее[10]. В связи с чем, целесообразно дальнейшее проведение исследований по выявлению роли цитокинов в развитии ХСН при ДТЗ. Цель работы : исследовать уровень АТ-рТТГ, ИЛ-6, ИЛ-8, ИЛ10 , ФНО- $\alpha$ у больных ДТЗ с ХСН и без нее, определить возможность влияния иммунологических изменений на формирование сердечно-сосудистых осложнений ДТЗ.

\section{Материалы и методы исследования}

Обследовано 68 пациентов с впервые установленным диагнозом ДТЗ (50 женщин $(73,5 \%)$ и 18 мужчин $(26,5 \%))$, ранее не получавших лечения. Лабораторными критериями подтверждения диагноза были повышение концентрации fT4, супрессия ТТГ менее 0,1 мМе/мл, обнаружение АТ-рТТГ более 1,58 MЕ/л. Согласно критериям включения возраст обследуемых составлял от 18 до 45 лет для мужчин, от 18 до 55 лет для женщин; медиана возраста в обследуемой популяции составила - 43,0 [30,0; 45,5]. Степень тяжести тиреотоксикоза оценивалась согласно национальному руководству по эндокринологии 2013г. [9], и по данному показателю распределение пациентов было следующим: средне-тяжелая форма обнаружена в 55,9\% случаев (38 пациентов), тяжелая - в 44,1\% (30 пациентов).

Диагноз ХСН устанавливался в соответствии с рекомендациями ОССН, РКО и РНМОТ от 2013 г. ХСН диагностирована в 55,9\% случаев (у 38 больных). У 12 пациентов выявлена 1 стадия ХСН $(31,6 \%)$, у 19 (50\%) - 2А стадия и у 7 (18,4\%)- 2Б стадия ХCH. Было учтено, что некоторые симптомы (тахикардия, снижение толерантности к физическим нагрузкам, одышка), которые позволяют диагностировать ХCH 1 стадии могу быть характерны и для самого ДТЗ, поэтому пациенты с XCH 1ст. были выделены в отдельную группу. Таким образом, сформировано 3 группы больных: 1 - пациенты с ДТЗ без признаков ХCH, 2 - пациенты с ДТЗ и ХСН 1 стадии, 3 пациенты с ДТЗ и ХCH 2А и 2Б стадий. Контрольную группу составили 30 здоровых лиц, сопоставимых по полу и возрасту с обследуемой группой. Из исследования исключались пациенты с наличием в анамнезе любой сердечно-сосудистой патологии, аутоиммунными заболеваниями, эндокринной офтальмопатией, онкологическими заболеваниями, острыми воспалительными и обострением хронических воспалительных заболеваний, психическими заболеваниями, беременностью и лактацией

Статистический анализ данных проводили в пакете прикладных программ STATISTICA 7.0 (StatSoft, Inc., 2004). Так как распределение признаков отличалось от 
нормального, данные представлены в виде медианы и межквартильнх интервалов. Для получения оценки вероятности р использованы непараметрические критерии МаннаУитни (Mann-Whitney U-test), Фишера (Fisher exact p), коэффициент корреляции Спирмена. Критический уровень значимости при проверке статистических гипотез принимали равным 0,05 .

\section{Результаты}

Медиана возраста пациентов в 1 группе составила 42,5 [29,0; 45,0], во 2 группе $40,0[29,5 ; 45,5]$, в 3 группе - 44,0 [36,0; 50,0], в группе контроля - $41[33,0 ; 45,0]$ $(\mathrm{p} \leq 0,05)$. Среди пациентов с ХCH количество мужчин было больше чем в группе 1 (16,7\% в 1-й группе, 33,3\% - во второй и 34,6\% в 3-ей), но данные различия оказались статистически не значимы $(\chi 2=2.658, \mathrm{p}>0.05)$. Все группы также были сопоставимы по возрасту. Уровень ТТГ, Т4св сыворотки крови были выше у пациентов с ДТЗ, чем в группе контроля $(\mathrm{p} \leq 0,05)$. Концентрация ТТГ между группами 1,2 и 3 не различалась $(\mathrm{p}>0,05)$. Концентрация Т4св была выше у пациентов с ХСН 2А и 2Б, чем у пациентов 1 и 2 групп ( $\mathrm{p} \leq 0,01)$. По длительности заболевания все три группы существенно не отличались друг от друга $(\mathrm{p}>0,05)$. При исследовании АТ-рТТГ их уровень был достоверно выше среди пациентов с ДТ3 (в 1-й группе - 13,6[6,5; 30,2], в группе №2 $14,2[6,1 ; 36,9]$ и $14,4[5,8 ; 34,1]$ в 3-й группе) по сравнению с группой контроля $(\mathrm{p} \leq 0,05)$, при сравнении между 1,2 и 3 групп по этому показателю, значения его оказались сопоставимы между собой (p>0,05). Данные представлены в таблице 1.

Таблица 1

Характеристика пациентов с ДТЗ и контрольной группь

\begin{tabular}{|c|c|c|c|c|}
\hline & Группа №1 & Группа №2 & Группа №3 & $\begin{array}{l}\text { Контрольная } \\
\text { группа }\end{array}$ \\
\hline $\begin{array}{c}\text { Количество } \\
\text { пациентов }\end{array}$ & 30 & 12 & 26 & 30 \\
\hline Возраст & $42,5[29,0 ; 45,0]^{*}$ & $40,0[29,5 ; 45,5]^{*}$ & $44,0[36,0 ; 50,0]^{*}$ & $41[33,0 ; 45,0]$ \\
\hline Пол & $\begin{array}{l}\text { 83,3\% женщин; } \\
\text { 16,7\% мужчин* }\end{array}$ & $\begin{array}{l}\text { 66,7\% женщин; } \\
\text { 33,3\% мужчин* }\end{array}$ & $\begin{array}{l}\text { 65,4\% женщин; } \\
34,6 \% \text { мужчин** }\end{array}$ & $\begin{array}{c}\text { 66,7\% женщин; } \\
\text { 33,3\% мужчин }\end{array}$ \\
\hline $\begin{array}{c}\text { Длительность } \\
\text { заболевания } \\
\text { (месяцев) }\end{array}$ & $5,2[1,3 ; 8,7]$ & $4,6[2,1 ; 9,1]$ & $4,9[1,7 ; 8,2]$ & (2) \\
\hline ТТГ, мМЕ/л & $\begin{array}{c}0,0125[0,01 ; \\
0,025]^{* *}\end{array}$ & $0,01[0,003 ; 0,02]^{* *}$ & $0,02[0,01 ; 0,04]^{* *}$ & $1,67[1,2 ; 3,6]$ \\
\hline fT4, пмоль/л & $38,85[34,0 ; 45,1]^{* *}$ & $\begin{array}{c}40,65[33,25 ; \\
48,45]^{* *}\end{array}$ & $63,2[39,8 ; 83,0]^{* *}$ & $18,22[15,4 ; 19,7]$ \\
\hline $\begin{array}{c}\text { Объем } \\
\text { щитовидной } \\
\text { железы, мл }\end{array}$ & $22,65[18,9 ; 28,9]^{* *}$ & $26,0[22,4 ; 31,1]^{* *}$ & $34,6[18,1 ; 87,1]^{* *}$ & $15,6[12,5 ; 20,4]$ \\
\hline
\end{tabular}

Концентрация АТ-рТТГ и всех исследуемых цитокинов у пациентов с ДТЗ (1-3 группы) была достоверно выше, чем в контрольной группе $(\mathrm{p} \leq 0,05)$.

При сравнении групп больных ДТЗ между собой различий по концентрации АТpТТГ не выявлено (p>0,05). По результатам анализа отмечено, что у пациентов с ДТЗ и ХСН 2А и 2Б уровни ИЛ-6 (группа 1 - 8,4 [7,8; 11,5], группа 2-8,55 [7,9; 11,4], группа 3 - 15,45 [11,9; 18,6]; p1-3 $\leq 0,05, \mathrm{p} 2-3 \leq 0,05)$, ИЛ-8 (группа 1 - 8,2 [7,3; 10,4], группа 2- 8,95 [7,5; 12,1], группа 3 - 16,8 [7,7; 65,9]; p1-3 $\leq 0,05, \mathrm{p} 2-3 \leq 0,05)$, ИЛ-10 (группа 1 - 29,0 [25,9; 33,2], группа 2 - 29,5 [19,35; 38,55], группа 3 - 43,6 [34,5; 69,7]; p1-3 $\leq 0,05, \mathrm{p} 2-3 \leq 0,05)$ были значительно выше, чем в группах 1 и 2. Иммунологические показатели полученные при обследовании пациентов, представлены в табл.2. 
Таблица 2

Иммунологическая характеристика пациентов с ДТЗ и группы контроля

\begin{tabular}{|c|c|c|c|c|}
\hline & Группа №1 & Группа №2 & Группа №3 & $\begin{array}{c}\text { Контрольная } \\
\text { группа }\end{array}$ \\
\hline АТ-рТТГ, Ед/л & $13,6[6,5 ; 30,2]$ & $14,2[6,1 ; 36,9]$ & $14,4[5,8 ; 34,1]^{*}$ & $0,01[0,0 ; 0,67]$ \\
\hline ИЛ-6, пг/мл & $8,4[7,8 ; 11,5]$ & $8,55[7,9 ; 11,4]$ & $15,45[11,9 ; 18,6]^{* *}$ & $3,42[1,9 ; 3,9]$ \\
\hline ИЛ-8, пг/мЛ & $8,2[7,3 ; 10,4]$ & $8,95[7,5 ; 12,1]$ & $16,8[7,7 ; 65,9]^{* *}$ & $6,55[3,8 ; 9,15]$ \\
\hline ИЛ-10, пг/мл & $29,0[25,9 ; 33,2]$ & $29,5[19,35 ; 38,55]$ & $43,6[34,5 ; 69,7]^{* *}$ & $9,3[4,1 ; 11,2]$ \\
\hline ФНО- $\alpha$, пг/мЛ & $6,75[5,8 ; 7,9]$ & $6,65[5,95 ; 11,2]$ & $8,0[6,5 ; 12,5]$ & $4,28[1,8 ; 5,3]$ \\
\hline
\end{tabular}

Выявлена прямая корреляция между нарастанием стадии ХСН и уровнем ИЛ-6 $(\mathrm{r}=0,52, \mathrm{p} \leq 0,001)$, ИЛ-8 $(\mathrm{r}=0,41, \mathrm{p} \leq 0,001)$ и ИЛ-10 $(\mathrm{r}=0,39, \mathrm{p} \leq 0,01)$. Ассоциации повышенной концентрации ФНО- $\alpha$ и АТ-рТТГ с формированием ХСН у пациентов с ДТЗ не получено.

\section{Обсуждение результатов}

ДТЗ - хронической аутоиммунное заболевание, ведущую роль в патогенезе которого играют АТ-рТТГ. По данным проведенного исследования для пациентов с тиреотоксикозом (не зависимо от степени тяжести) характерно значимое повышение концентрации АТ-рТТГ, в сравнении со здоровыми лицами. Также выявлено статистически значимое повышение уровней ИЛ-6, ИЛ-8, ИЛ-10 и ФНО- $\alpha$ по сравнению с контрольной группой. При этом концентрация ИЛ-6, ИЛ-8 и ИЛ-10 достоверно выше у пациентов с ДТЗ в сочетании с ХCH 2а и 2б, чем у больных без признаков ХCH или с ХCH 1 стадии. На основании полученных данных можно предположить, что существует прямая взаимосвязь между развитием тяжелого поражения сердечно-сосудистой системы (с формированием $\mathrm{XCH}$ ) при ДТ3 с активацией системы цитокинов.

\section{Выводы}

1. Для пациентов с ДТЗ по сравнению с контрольной группой характерно значимая активация системы цитокинов с повышением концентрации как провосполительных (ИЛ-6, ИЛ-8, ФНО- $\alpha$ ), так и противовоспалительных фракций (ИЛ-10).

2. Развитие поражения сердечно-сосудистой системы с формированием ХСH при ДТЗ ассоциировано с повышением концентрации ИЛ-6, ИЛ-8 и ИЛ-10.

3.Прямой корреляции между уровнем АТ-рТТГ и ФНО- $\alpha$ с развитием ХСН у пациентов с ДТЗ не выявлено.

$$
* * *
$$

1. Bahn RS, Burch HB, Cooper DS, et al. Hyperthyroidism and other causes of thyrotoxicosis // Endocrine Practice. - 2011. - №17 - P. 520.

2. Эндокринология: Руководство для врачей / В.В. Потемкин [ и др.]. - М.: ООО "Медицинской информационное агентство", 2013. - 776с.

3. Иммунология / под ред. Ройтта А., Бростоффа Дж., Дейла Д.; пер. с англ.- М.: «Логосфера», 2007 $568 \mathrm{c}$.

4. Esfahanian F., Naimi E., Doroodgar F. et al. Th1/Th2 Cytokines in Patients with Graves' Disease with or without Ophthalmopathy // Iran J. Allergy Asthma Immunol. - 2013. -12(2) - P.168-175.

5. Michels AW, Eisenbarth GS. Immunologic endocrine disorders // J Allergy Clin Immunol. - 2010. 125(2). - 226-237.

6. Lumachi F, Basso SM, Orlando R. Cytokines, thyroid diseases and thyroid cancer // Cytokine. - 2010. 50(3). - P. 229-33.

7. Салихова А.В., Фархутдинова Л.М. О роли иммунной системы в развитии кардиоваскулярных нарушений при диффузном токсическом зобе // Цитокины и воспаление. - 2013. - N 3. - С. 18-20.

8. Серебрякова О.В. Патогенетические механизмы формирования кардиомиопатии при тиреотоксикозе и гипотиреозе. Автореферат на соискание ученой степени доктора медицинских наук. Чита, 2008. 
9. Латогуз И.К., Зимина М.С. Активность цитокинов при тиреотоксической кардиомиопатии // Врач. 2005. - N2. - C. 23-26.

10. Гома Т.В., Хамнуева Л.Ю., Орлова Г.М. Клинико-иммунологические аспекты поражения сердечнососудистой системы у больных с болезнью Грейвса и хронической сердечной недостаточностью // Клиническая и экспериментальная тиреоидология. - 2011. - том 7, №3. - С.42-47.

11. Эндокринология. Национальное руководство / под ред. И. И. Дедова, Г. А. Мельниченко. - М.: ГЭОТАР-Медиа, 2013. - 1084 с.

\section{Чиркова Н.В., Плутахина А.А., Лещева Е.А., Машкова Н.Г., Кузнецов Д.Э. Изучение комплаентности и ее взаимосвязи со стоматологической заболеваемостью у студентов}

Воронежский государственный медицинский университет им.Н.Н. Бурденко» Министерства Здравоохранения РФ

(Россия, Владивосток)

doi:10.18411/spc-15-11-2017-10

idsp: 000001:spc-15-11-2017-10

Известно, что гигиенические и лечебные стоматологические мероприятия не будут эффективными без формирования у пациента ответственности за здоровье органов и тканей полости рта. При этом, возрастает роль соблюдения больным предписаний врача, так как профилактика и лечение заболеваний пародонта требует длительных сроков, а их прекращение приводит к обострению и возрастанию их степени тяжести. По данным ВОЗ, около 45-50\% пациентов с хроническими заболеваниями пародонта не выполняют медицинские рекомендации, что приводит к серьезным медицинским и социальным последствиям. Поведение больного в отношении правильности приема назначенных лекарственных препаратов, точности выполнения назначаемых нелекарственных процедур, следования прописанной диете, ограничения имеющихся вредных привычек и формирования здорового образа жизни описывает термин compliance, что дословно означает уступчивость, податливость, согласие, одобрение. Проблема комплаентности увеличилась в связи с тем, что внимание стоматологов все больше акцентрируется не только на устранении симптомов, но и на предупреждении обострений стоматологических заболеваний. Уделяется большое значение соблюдениям пациентов режима лекарственных назначений и стоматологических рекомендаций. В зарубежной литературе особое значение придаётся положительной комплаентности в пародонтологической практике. Эффективность лечебных мероприятий зависит от ряда факторов и, в первую очередь, - от комплаентности пациента. Отмечена связь между ней и утратой зубов в связи с патологией пародонта, удалением зубов по этому поводу, ремиссией заболевания.

На формирование комплаентности оказывают влияние такие факторы, как психологические особенности больного и личностные особенности больного.

В последнее время уровень здоровья студенчества все более привлекает внимание, однако он продолжает оставаться невысоким. За время обучения наблюдается рост заболеваемости органов пищеварения, снижения числа здоровых студентов, увеличение лиц, имевших два и более заболевания. Студенты- одна из наименее незащищенных групп населения. В настоящее время актуальной является проблема распространения стоматологических заболеваний среди студентов. Значительное влияние на состояние полости рта оказывают факторы риска, связанные с социально-экономическими условиями жизни людей, их привычками, состоянием соматического здоровья. 
Обучение в высших учебных заведениях предъявляет высокие требования к состоянию здоровья студентов. Установлено, что для студентов отсутствие вредных привычек и правильное питание не являются составляющими здорового образа жизни. Недостаточно хорошо изученными являются значимость, частота социальногигиенических факторов риска поведенческого характера, а именно табакокурения, объем гигиенических мероприятий

На кафедре пропедевтической стоматологии ВГМУ им. Н.Н. Бурденко по данным анкетирования $и$ объективной оценки была проведена оценка стоматологической комплаентности у 100 студентов 2 u 3 курсов стоматологического факультета.

В результате обследования студентов был выявлен кариес и его осложнения у $83,5 \%$, интенсивность кариозного процесса (КПУ) составила 4,21 10,3 зуба на одного обследованного. Нуждаемость в лечении составила в среднем на одного студента 1,12 зуба, подлежащего лечению.

Заболевания пародонта определень у 79\%, кровоточивость десен у 25,2\%, зубной камень у 54,1\%, пародонтальные карманы менее 5 мм обнаружены у 12,3\% студентов.

Анализ состояния здоровья студентов выявил наличие ряда соматических заболеваний (патология со стороны органов ЖКТ, бронхиальная астма, артериальная гипертензия). У студентов, имеющие заболевания ЖКТ чаще обнаруживались заболевания твердых тканей полости рта.

Выявлено отрицательное влияние табакокурения на ткани пародонта. У курящих студентов выше интенсивность кариеса и выше индекс гигиены. Также у них вылвлялся зубной камень, пародонтальные карманы.

Анализ отношения студентов к стоматологической помощи и проблем профилактики заболеваний полости рта показал, что только 5\% студентов до поступления в вуз регулярно посещяали стоматолога с профилактической иелью. На 3 курсе число студентов, регулярно посещающих стоматолога для профилактики стоматологических заболеваний возросло до 35,1\%. Определение объема выполнения гигиенических мероприятий по уходу за полостью рта у студентов в зависимости от их психо-эмоционального состояния (уровня личной тревожности, депрессивности) показало, что общее число тех, кто выполнял хотя бы одну рекомендацию по гигиеническому уходу за полостью рта, было больше среди студентов со средним уровнем тревожности, по сравнению со студентами с высоким и низким уровнем тревожности. Студенты с отсутствием депрессивности чаще проводили гигиенические мероприятия, чем студенты с субдепрессивным состоянием или легкой степенью депрессии.

Полученные данные о факторах риска, распространенности, структуре заболеваний полости рта среди лиц молодого возраста необходимо учитывать при разработке программ планирования стоматологической помощи студентам вузов, направленных на снижение уровня заболеваемости твердых тканей полости рта.

Таким образом, комплаентное поведение пациентов молодого возраста зависит от мотивации к поддержанию здорового образа жизни и гигиене полости рта. Следует помнить и о том, что основные факторы, определяющие комплаентное отношение к стоматологическому лечению пациентов - это возраст, гендерные признаки, уровень образования, социальное положение, а также психологические факторы. Полная и доступная информация о лечении стоматологических заболеваний является основанием 
для осознанного принятия пациентом назначений и рекомендаций врача-стоматолога. Ответственное отношение к своему здоровью, желание больного следовать рекомендациям врача во время лечения различной патологии челюстно-лицевой области связано не только с социальными факторами, но и характером нозологии, ее клиническим течением, прогностическими данными.

$$
\text { *** }
$$

1. Голева Н.А. Стоматологический комплаенс у жителей Смоленской области // Вестник Смоленской медицинской академии. - 2008. - № 2. - С. 105-107.

2. Данилов Д.С. Комплаенс в медицине и методы его оптимизации (клинические, психологические и психотерапевтические аспекты) // Психиатрия и психофармакотерапия. -2008. - Т.10, № 1. - С. $13-20$.

3. Коммунальная стоматология: учебно-методическое пособие / А.Н. Морозов и [др.]. - Воронеж, 2016. $-125 \mathrm{c}$.

4. Лутова Н.Б., Незнанов Н.Г., Вид В.Д. Коплаенс в психиатрии и способ его оценки // Психиатрия и психофармакотерапия. - 2008. - Т.10, № 1. - С. 8-12.

5. Пропедевтика хирургической стоматологии: учебное пособие / А.Н. Морозов и [др.]. // Международный журнал прикладных и фундаментальных исследований. - 2014. № 3. С. 158-159.

\section{Чиркова Н.В., Вавина А.П., Корецкая И.В., Мамонтова А.М.,Колесников И.Р. Изучение основных проблем современной эндодонтии - микробной флоры биопленки}

Воронежский государственный медицинский университет им.Н.Н. Бурденко» Министерства Здравоохранения РФ (Россия, Владивосток)

doi:10.18411/spc-15-11-2017-11

idsp: 000001:spc-15-11-2017-11

Известно, что апикальный периодонтит является своеобразной защитной реакцией организма на действие продуктов жизнедеятельности одонтогенной флоры. Достаточно сложная анатомия корневых каналов обеспечивает благоприятную среду для роста, размножения и взаимодействия микроорганизмов. Они присутствуют во всех частях корневых каналов, включая боковые каналы, анастомозы и дентинные канальцы в глубине до 300 микрон со стороны пульпы. Исследования флоры инфицированных корневых каналов дали следующую картину: преобладание смешанной флоры. Максимально высокие проценты показали Enterococcus faecalis $(49 \%)$ и Porhyromonas gingivalis $(17,6 \%)$. После лечения некоторые стойкие микроорганизмы, такие как Enterococcus Faecalis и Candida Albicans, могут поддерживать периодонтит и определять неудачный исход эндодонтического лечения.

Enterococcus - род бактерий семейства Enterococcaceae, часто представлены парами (диплококки) или короткими цепочками, трудноотличимы от стрептококков по физиологическим характеристикам. Основными симбиотическими организмами кишечника человека: Enterococcus faecalis (90-95 \%) и Enterococcus faecium (5-10 \%). Enterococcus faecalis- факультативные анаэробы, способные осуществлять клеточное дыхание как в бескислородной, так и насыщенной кислородом среде. Спор не образуют, однако устойчивы в широком диапазоне условий. Растут при температуре $+10 \ldots+45{ }^{\circ} \mathrm{C}, \mathrm{pH} 4,5-10,0$, а также при высоких концентрациях хлорида натрия. Энтерококки, входящие в состав нормальной микрофлоры пищеварительного тракта человека, играют важную роль в обеспечении колонизационной резистентности слизистых. Способнывызывать аутоинфекцию. Энтерококки высокорезистентны к различным факторам внешней среды и дезинфицирующим средствам,выдерживают нагревание до $60^{\circ} \mathrm{C}$ в течение 30 минут. Среди заболеваний, вызываемыми энтерококками,можно выделить следующие: эндокардит, инфекции кожи и мягких тканей, инфекции дыхательных путей, бактериемии, а также все воспалительные 
заболевания одонтогенной природы, такие как пульпит, периодонтит, периостит, остеомиелит.

Порфиромонады - вид условно-патогенных бактерий рода Porphyromonas, состоящего из 3 видов: Р. asaccharolyticus (типовой вид), Р. gingivalis, P. endodontalis. Порфиромонады инертны к углеводам, образуют индол, рост стимулирует внесение в среду глюкозы, цистеина и др. Porphyromonasgingivalis связывает и разрушает фибриноген, секретирует коллагеназу, участвующую в повреждении дентина, а также агглютинирует эритроциты. У человека порфиромонады вызывают гингивиты, периодонтиты, поражения мягких тканей головы и шеи, аспирационные пневмонии. Культуры порфиромонад имеют гнилостный запах. Рост порфиромонад ингибируют жёлчные соли (20\%); бактерии чувствительны к ванкомицину, но резистентны к колистину и канамицину. Выделены при инфекциях полости рта и канала зуба. Вызывают гнойно-воспалительные заболевания челюстно-лицевой области.

Candidaalbicans- это представитель простейших дрожжеподобных грибов, ведущих исключительно паразитирующий образ жизни. Наибольшее их количество встречается в тканях, богатых этим веществом, а именно в слизистых кишечника, пищевода, гортани,ротовой полости.К факторам патогенности у грибов рода Candida относится секреция протеолитических ферментов и гемолизинов, дерматонекротическая активность и адгезивность.

Фузобактерии - тип грамотрицательных, анаэробных неспорообразующих бактерий. Полиморфны, часто имеют форму толстых длинных палочек с заостренными концами размером 0,5-1 на 2-3 мкм, не имеют жгутиков и не образуют капсул. Фузобактерии входят в состав нормофлоры верхних дыхательных путей, желудочнокишечного тракта и половых путей. Некоторые виды фузобактерий являются условнопатогенными и при иммунодефицитах могут вызывать вторичные гангренозные и гнойно-гангренозные процессы. При ангине, герпетическом стоматите, гипотрофии у детей, при иммунодефицитных состояниях возможно развитие фузоспирохетоза некротического воспалительного процесса на миндалинах, слизистой оболочки полости рта.

Биоплёнка- устойчивый конгломерат микроорганизмов, расположенных на какой-либо поверхности, клетки которого прикреплены друг к другу. Обычно клетки погружены в выделяемое ими внеклеточное полимерное вещество (внеклеточный матрикс).Биопленки играют очень важную роль в заболеваниях пульпы и периодонта.85\% объема биопленки занимает матрикс из полисахаридов и белков.Микробная биопленка рассматривается как сообщество, которое соответствует следующим критериям: оно должно обладать способностью к самоорганизации (автопоэз), сопротивлению к окружающей среде (гомеостаз), должно быть более эффективным во взаимодействии, чем в изоляции (синергизм), и реагировать на различные изменения как единое целое, а не отдельно (сообщность).

Сложность в удалении биопленки с поверхности корневого канала обусловлена несколькими факторами. Во-первых, сложностью строения и структуры биопленки, в которой микроорганизмы погружены в матрикс, являющийся защитным слоем и одновременно питательной средой. Во-вторых, это сложившиеся механизмы адаптации биопленок, которые предусматривают регулирование обширного набора генов. Кроме того, процесс «построения» биопленки является сложным и поэтапным, включающим осаждение (первичное и окончательное прикрепление), созревание, рост и дисперсию (выброс бактерий). В процессе адаптации биопленок в регуляторной системе важную роль играет гистидинкиназа - фермент, передающий фосфатные группы другим молекулам сигнального пути, участвующего в механизме адаптации.Он включает в себя активацию гистидинкиназы, которая затем по отдельности реагирует с каждой из примерно 20 потенциальных мишеней. Мишени, которым гистидинкиназа быстро передает фосфатные группы, должны быть частью сигнального пути. Гистидинкина 
зафосфорилирует три белка, называемые регуляторами ответа, которые, работая вместе, контролируют образование биопленки. Каждый регулятор играет комплементарную роль, составляя вместе с двумя другими необычайно сложную систему. Биопленки выработали определенные механизмы защиты к противомикробным препаратам. Микроорганизмы в биопленках живут в «замедленном» метаболическом состоянии. Полисахаридная матрица замедляет диффузию антибиоткиков и других противомикробных препаратов. Кроме того, внеклеточные ферменты, такие как $\beta$-лактамазы могут попасть в ловушку и концентрируются в матрице, что приводит кинактивации $\beta$-лактамных антибиотиков. Бактерии защищают себя, находясь во внутренней части биопленки. Значит, лекарственные вещества могут действовать только на микроорганизмы в периферийной части биопленки. Бактериальные клетки, находящиеся в биопленке, растут медленнее, чем другие клетки, и, как следствие, антимикробные агенты действуют медленнее. Истощение питательных веществ или накопление отходов может привести к вводу микроорганизмов в невегетативное состояние, которое защищает их от антибиотиков, а также снижает дозу и частоту воздействия противомикробного препарата.Химические изменения в биопленке по отношению к окружающей среде, где недостаток кислорода ингибирует некоторые антибиотики, а также накопление кислотных отходов, приводит к изменению $\mathrm{pH}$, который имеет влияние на антагонистические антибиотики.На основании анализа об эндоканальных микроорганизмах и биопленке, можно сделать следующие выводы. После применения внутриканальных медикаментов бактерии могут выживать несколькими способами:

1)бактерии в корневом канале могут быть устойчивыми к медикаменту;

2)бактериальные клетки могут быть далеки от воздействия медикамента (канальцы, боковые каналы и ответвления);

3)медикаментозное средство может нейтрализоваться тканевыми компонентами (буферными системами) или продуктами бактериальных клеток;

4)медикаментозное средство может оставаться в корневом канале недостаточное время для уничтожения бактерий;

5)бактерии могут изменить свои генные свойства после изменения окружающей среды, что помогает им выжить в неблагоприятных условиях.

Таким образом, поиск оптимального эффективного медикамента для обработки корневых каналов, как никогда актуален и необходим ввиду устойчивости и изменчивости микроорганизмов, их способности к образованию биопленок.

$$
* * *
$$

1. Апокина А.Д. Анатомия зубов и эндодонтический доступ /Апокина А.Д., Кутяев С.А. //М.: Издательство Александра Рутмана, 2008. - 120с.

2. Доменико Рикуччи. Эндодонтология. Клинико-биологические аспекты /Доменико Рикуччи, ЖозеСикейра //М: Азбука, 2015. - 415с.

3. ЗаидоАбдулкадер. Роль антисептической лечебно-профилактической жидкости во время стоматологического приема / ЗаидоАбдулкадер, А.Н.Морозов, Ж.В.Вечеркина // Системный анализ и управление в биомедицинских системах, 2014.-Т.13,№4.-С.847-850.

4. Пропедевтика хирургической стоматологии: учебное пособие / А.Н. Морозов и [др.]. // Международный журнал прикладных и фундаментальных исследований. - 2014. № 3. С. 158-159.

5. Структурно-функциональная характеристика бактериальных биопленок /Смирнова Т.А., Диденко Л.В., Азизбекян Р.Р.// Микробиология. 79 (4), 2010. - С. 435-446. 


\section{SCIENCEPUBLIC}

Научное издание

Научный диалог:

Вопросы медицины

Сборник научных трудов, по материалам

$\mathrm{X}$ международной научно-практической конференции

15 ноября 2017 г.

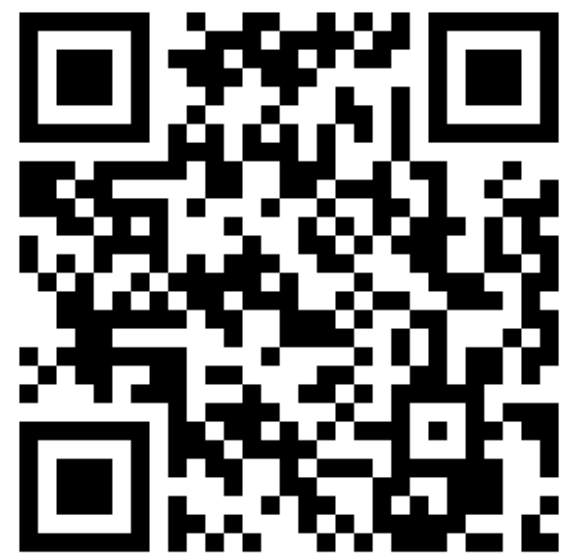

SPLN 001-000001-0205-MQ

Подписано в печать 18.11.2017. Тираж 400 экз.

Формат.60х841/16. Объем уч.-изд. л.2,07

Бумага офсетная. Печать оперативная.

Отпечатано в типографии НИЦ «Л-Журнал»

Главный редактор: Иванов Владислав Вячеславович 